\title{
Valparaiso University
}

ValpoScholar

2010

\section{Dickens Redux: How American Child Labor Law Became a Con Game}

Seymour Moskowitz

Valparaiso University School of Law

Follow this and additional works at: http://scholar.valpo.edu/law_fac_pubs

Part of the Human Rights Law Commons, Labor and Employment Law Commons, and the $\underline{\text { Social Welfare Law Commons }}$

\section{Recommended Citation}

Seymour Moskowitz, Dickens Redux: How American Child Labor Law Became a Con Game, 10 Whittier J. Child \& Fam. Advoc. 89 (2010).

This Article is brought to you for free and open access by the Law Faculty Presentations and Publications at ValpoScholar. It has been accepted for inclusion in Law Faculty Publications by an authorized administrator of ValpoScholar. For more information, please contact a ValpoScholar staff member atscholar@valpo.edu. 


\title{
DICKENS REDUX: HOW AMERICAN CHILD LABOR LAW BECAME A CON GAME
}

\author{
SEYMOUR MOSKOWITZ*
}

\begin{abstract}
Millions of American teens are employed today in a variety of workplaces. The jobs they hold typically provide little human capital for their future economic self-sufficiency, and pose substantial immediate and long-term safety, academic, and behavioral risks for this generation. This Article seeks to answer the question of how American law and society reached this situation, which has such disastrous effects for working youth, their families, and society as a whole. Three main themes are developed:
\end{abstract}

1. Child labor has always been part of the American economy, from colonial times until today. While there have been more than 150 years of effort to curtail youth employment, this movement has been generally unsuccessful at both federal and state levels.

2.The federal courts, and particularly the United States Supreme Court, defeated repeated statutory attempts to restrict child labor. This judicial activism is demonstrated by the previously untold factual and

\footnotetext{
* Professor of Law, Valparaiso University School of Law. Parts of this Article were originally presented at the Annual Colloquium on Current Developments in Labor and Employment Law and at several Work-in-Progress sessions. I thank the many colleagues who provided critiques and suggestions for further research, and Professors Ivan Bodensteiner and Rosalie Levinson for insightful comments. Invaluable research assistance was provided by Abby Rom and Nathan Vis, both Valparaiso University School of Law, 2010. As always, my colleague Melissa Mundt contributed indispensible support.
} 
legal history of several cases, especially the famous decision in Hammer v. Dagenhart.

3. With Locknerism finally demolished by the Great Depression of the 1930s, the passage of the Fair Labor Standards Act of 1938 was to be the death knell for child labor. This victory was, in fact, pyrrhic. The weaknesses of the FLSA resulted in the continuation of youth employment. These statutory deficiencies were the outcome of a toxic combination of factors: profits from cheap labor, entrenched and powerful economic interests, and racism.

\section{TABLE OF CONTENTS}

I.INTRODUCTION 90

II.HISTORY OF CHILD LABOR REGULATION IN THE

UNITED STATES. .98

A. The Formative Period and Subsequent Industrialization.... 98

B. Reform Efforts and the Progressive Era............................ 105

III.ACTION AT THE FEDERAL LEVEL ..................................................... 110

A. Roland Dagenhart and the Supreme Court....................... 112

1. Impact of the Decision............................................... 124

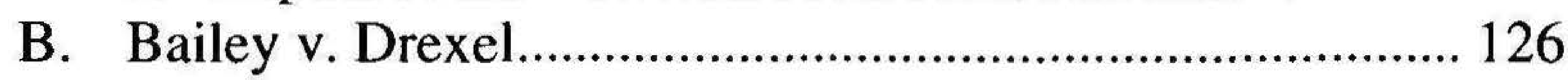

IV.FEDERAL ACTIVITY IN THE 1920S AND 1930S ............................. 132

A. The Twentieth Amendment............................................. 132

B. Developments in the Great Depression ............................. 137

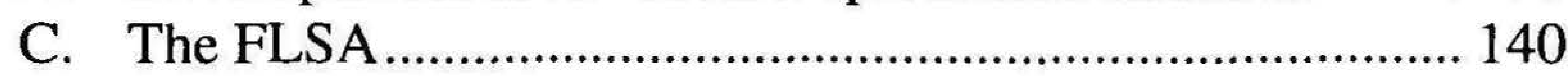

D. The Impact of the FLSA on Child Labor .......................... 143

E. The Agricultural Exclusion ................................................ 148



\section{I.INTRODUCTION}

Charles Dickens' fictional portrayal of nineteenth century English child labor was based largely on his own youthful factory experience while his father sat in debtor's prison. ${ }^{1}$ The vivid descriptions of

1. When his father was sent to Pauper's Prison Charles Dickens was forced to work in a shoe blacking factory, where his peers called him "scholar." Dickens later described himself in David Copperfield: "a child of excellent abilities and with strong power of observation, quick, eager, delicate and soon hurt bodily, or mentally." 
abandonment and exploitation in Oliver Twist, David Copperfield, and other novels were powerful protests against a system that robbed youth of childhood and long-term life prospects for employer profit. While Parliament ultimately passed statutes ostensibly safeguarding child workers, these laws provided only limited protection and were rarely enforced. $^{2}$ On this side of the Atlantic, children ${ }^{3}$ have been an integral part of the labor market from the founding of the American colonies to our contemporary globalized economy.

In the United States, after an extraordinary campaign spanning more than half a century, Congress enacted national legislation on child labor. ${ }^{4}$ Since the passage of the Fair Labor Standards Act (FLSA) in 1938, public policy on child labor has changed little. The federal statute and similar state laws barred children under eighteen from mining and manufacturing worksites producing goods in interstate commerce. 5 The FLSA also proscribed "oppressive child labor." 6

Charles Dickens, David Copperfield Vol. I in The Works of Charles Dickens 184 (Charles Scribner's Sons 1899). His personal experience was mirrored in almost all his works together with the images of the conditions he saw while forced to work to support his family. Robert Langton, The Childhood and Youth of Charles Dickens 7280 (The Author at Albert Chambers 1891).

2. The most important Factory Acts regulating the hours of labor for both adults and children were passed in 1833, 1844, and 1847. See generally John Ward, The Factory Movement: 1830-1855 (1962). Ward traces early efforts in England for reform of labor within factories. Labor advocates at this time noted sixteen-hour workdays of children working in ninety-degree factories, youth who "were industry cripples treated worse than dogs." Id. at 56. Three decades of advocacy ended with a sixty-hour workweek, which was rarely enforced. $I d$. at 346.

3. The U.S. common law recognizes legal adulthood as beginning at age eighteen or upon emancipation, marriage, or with parental consent. Douglas Abrams \& Sarah Ramsey, Children \& The Law 811 (3d ed., West 2007).

4. The term "child labor" is used here to describe paid employment by persons under eighteen years of age. "Youth workers" and other terms are used throughout this Article synonymously.

5. Fair Labor Standards Act of 1938, 29 C.F.R. $§ 570.2(a)(i)(2010) ; 29$ C.F.R. $\S 570.2$ (a)(ii) (2010); 29 U.S.C. § 203(1) (2010).

6. Children under age eighteen are barred from working in jobs administratively defined to be "particularly hazardous ... or detrimental to their health or well-being." 29 U.S.C. $\S 212$ (c) (2010). Even this limited protection is conditioned by specific exemptions for occupations other than manufacturing and mining, for example, agriculture. If the occupation has been declared hazardous by the Secretary of Labor, eighteen is the minimum age to work in that job. See 29 C.F.R. $\$ 570.120$ (2010). Those designations have remained unchanged since 1975. 29 C.F.R. $\S 570.67$ (2010). See infra notes 328-340 and accompanying text. 
Aside from those limits, adolescents over sixteen have no restriction on time or place of their work. ${ }^{7}$ Fourteen- to sixteen-year olds have some limited time restrictions, ${ }^{8}$ but are free to work in most worksites.

Today, the FLSA and equivalent state legislation ${ }^{9}$ are assumed to protect American youth workers from exploitation in the workplace. When Americans are at all cognizant of issues of child labor, the image is that of exploited children in Third World countries. Yet this soothing picture masks a very different reality. Despite the best efforts of American reformers for over 100 years, restrictions on child labor have remained more symbolic than real. Although some of the worst abuses of the nineteenth century have been abolished, at least five million American adolescents are at work after school; ${ }^{10}$ hundreds of thousands toil in agriculture. ${ }^{11}$ The United States has the highest percentage of working children of any developed nation.

7. Schmidt v. Reich, 835 F. Supp. 435, 444 (N.D. Ill. 1993).

8. Fourteen- to sixteen-year-olds may not work more than eighteen hours per week during the school year, nor after 7:00 p.m. on a school night. 29 C.F.R. $\S 570.35$ (a) (2010).

9. The FLSA explicitly does not pre-empt state child labor laws. 29 U.S.C. $\S 218(2010)$.

10. Millions of youths under eighteen are in the contemporary American workforce but the precise number remains elusive. The Child Labor Coalition (CLC) estimates 5.5 million youth age twelve to seventeen are in the workforce. Child Labor Coalition, Youth Employment Statistics, http://www.stopchildlabor.org/USchildlabor/ statistics.htm (accessed Jan. 25, 2011). Approximately 70-80\% of youth work in paid jobs at some point while attending high school. Alexis M. Herman, U.S. Dept. of Lab., Report on the Youth Labor Force 75, http://stats.bls.gov/opub/rylf/pdf/rylf2000.pdf (revised Nov. 2000).

11. Estimates concerning the number and makeup of child farmworkers vary widely. See Celeste Corlett, Impact of the 2000 Child Labor Treaty on U.S. Child Laborers, 19 Ariz. J. Intl. \& Comp. L. 713, 713 (2002) (estimating 800,000 to 1.5 million children age five to fifteen toil in harsh conditions in the U.S. agriculture industry). In 1998, the General Accounting Office (now the Government Accountability Office (GAO)) estimated that 300,000 youth aged fifteen to seventeen were working in agriculture. The U.S. Department of Agriculture's National Agricultural Statistics Services (NASS) stated that 431,730 youth between the ages of twelve and seventeen were hired for agricultural work in 1998. Association of Farm Workers Opportunity Programs, Children in the Fields: An American Problem 6, http://afop.org/download/11/ (2007). See Child Labor Coalition, Children in the Fields Campaign Fact Sheet, http://www.stopchildlabor.org/Consumercampaigns/fields.htm (2007) (estimating over 400,000 children between ages twelve to seventeen work in agriculture). Hospital emergency room and workers compensation data suggests that youth injuries in agriculture are more severe than those at other worksites. Child Labor Coalition, supra n. 10. 
Approximately $80-90 \%$ of youth work in paid jobs at some point while attending high school. ${ }^{12}$ Once having begun paid employment they usually continue to work with increasing frequency and intensity. Restrictions on the number of hours and the type of work they do are minimal $^{13}$ and penalties for violation of child labor laws are extraordinarily lax. ${ }^{14}$

This employment presents potential benefits for the adolescent, including income, valuable lessons about responsibility and finances, and transferrable job skills. However, children's work in the United States-most especially "high intensity" work, i.e., more than twenty hours per week ${ }^{15}$-poses substantial immediate and long-term academic, safety and health risks for youth workers. These adolescents have less academic success in high school ${ }^{16}$ and increased absence/drop-out rates than those who do not work or work fewer hours. ${ }^{17}$ They are also more likely to use cigarettes and other harmful

12. Herman, supra n. 10 , at 75 . Over half the youths interviewed by the DOL responded that they had held jobs at the age of fourteen; over $60 \%$ worked at age fifteen. Id. at 14-15. See also Ellen Greenberger \& Laurence D. Steinberg, When Teenagers Work: The Psychological and Social Costs of Teenage Employment 11 (Basic Books 1986).

13. While the child labor provisions of the FLSA provide some limits, a tangle of exemptions guarantees both complexity and non-coverage of many youth workers. Although the Act prohibits adolescents from working in hazardous occupations, adolescents over sixteen years of age have no federal restrictions on the number of hours or the time of day they may work. See Schmidt, 835 F. Supp. at 444. Additionally, the FLSA does not apply to youth employed in activities in an "enterprise" with less than $\$ 500,000$ per year in operations, 29 U.S.C. $\S 203(\mathrm{~s})(1)(\mathrm{A})(\mathrm{ii})$ (2009), or not affecting interstate commerce, although those workers may be protected by state statute.

14. Civil penalties of $\$ 1,000$ per violation were first added in 1974 because the injunctive and criminal sanctions were determined to be "insufficiently flexible." Fair Labor Standards Act $\S 16(\mathrm{e})$, Pub. L. No. 93-259 (codified as amended at 29 U.S.C. 216(e). See also Marshall v. Jerrico, Inc., 446 U.S. 238, 244 (1980).

15. Natl. Research Council Inst. Med., Protecting Youth at Work 3-4 (Natl. Acad. Press 1998).

16. For example, students working longer hours have lower grade point averages. See e.g., R. D'Amico, Does Employment During High School Impair Academic Progress? 57 Soc. Educ. 152, 152-64 (1984); Herbert W. Marsh \& Sabrina Kleitman, Consequences of Employment During High School: Character Building, Subversion of Academic Goals, or a Threshold? 42 Am. Educ. Res. J. 331, 331-369 (2005).

17. See generally Rhoda V. Carr, James D. Wright \& Charles J. Brody, Effects of High School Work Experience a Decade Later: Evidence From the National Longitudinal Study, 69 Soc. Educ. 66, 66-81 (1996); see generally Sharon Wofford Mihalic \& Delbert S. Elliott, Short- and Long-Term Consequences of Adolescent Work, 
substances, have more traffic accidents and teen pregnancies, and to experience a wide variety of other negative outcomes. ${ }^{18}$

The physical hazards of youth work have always been enormous; they remain so today. The numbers of children killed and injured on the job in the early twentieth century was well-documented. ${ }^{19}$ Today the workplace is the fourth most common cause of harm to American youths aged ten to nineteen. ${ }^{20}$ Fatalities of working youth are far too common. $^{21}$ Work-related injury rates for contemporary juvenile

28 Youth \& Socy. 464, 464-489 (1997); Jeylan T. Mortimer \& Monica Kirkpatrick Johnson, New Perspectives on Adolescent Work and the Transition to Adulthood, in New Perspectives on Adolescent Risk Behavior 425 (Richard Jessor ed., Cambridge U. Press 1998); Mark Schoenhals, Marta Tienda \& Barbara Schneider, The Educational and Personal Consequences of Adolescent Employment, 77 Soc. Forces 723, 723-762 (1998). More limited employment during adolescence (twenty hours or less per week during school) has been associated with reduced high school drop-out rates. R. D'Amico, supra n. 16, at 152-164; see Jennifer C. Lee \& Jeremy Staff, When Work Matters: The Varying Impact of Adolescent Work Intensity on High School Drop-Out, 80 Soc. Educ. 158, 158-178 (2007); see generally John Robert Warren \& Jennifer C. Lee, The Impact of Adolescent Employment on High School Dropout: Differences by Individual and Labor-Market Characteristics, 32 Soc. Sci. Res. 98, 98-128 (2003).

18. Richard Jessor \& Shirley L. Jessor, Problem Behavior and Psychological Development: A Longitudinal Study of Youth (N.Y. Acad. Press 1977) (describing alcohol use, smoking, drug use and sexual activity as symbolic claims to adult status). Negative outcomes associated with high-intensity work may result from "precocious development," the assertion of independent adult-like status by teens assuming "adult" roles because of school completion, employment, and individual decision-making. Jerald Bachman \& John E. Schulenberg, How Part-Time Work Intensity Relates to Drug Use, Problem Behavior, Time Use and Satisfaction Among High School Seniors: Are These Consequences or Merely Correlates?, 29 Dev. Psychol. 220 (describing "precocious adult-like identity" formation). These foster more deviant behavior, especially for those working with delinquent peers. Adolescents who are employed alongside delinquent coworkers tend to commit more workplace crime, as well as demonstrate more general deviance than do those who do not work with delinquent peers. See Matthew Ploeger, Youth Employment and Delinquency: Reconsidering a Problematic Relationship, 35 Criminology 659 (1997); John Paul Wright \& Francis T. Cullen, Juvenile Involvement in Occupational Delinquency, 38 Criminology 863 (2000).

19. See infra $\mathrm{nn}$. 59-65 and accompanying text.

20. Only motor vehicle accidents, violence, and recreation do more damage to American teens. See generally Center for Disease Control and Prevention, WorkRelated Injuries and Illnesses Associated with Child Labor-United States, 1993, 45 Morbidity \& Mortality Wkly. Rep. 464, 464-468 (1996); D. Laraque, B. Barlow \& M. Durkin, Prevention of Youth Injuries, 91 J. Natl. Med. Assn. 557, 557-571 (1999).

21. Paul A. Schulte et al., Integrating Occupational Safety and Health Information Into Vocational and Technical Education and Other Workforce 
workers are consistently between $60 \%-70 \%$ higher than the rates for workers of all ages and second only to rates for workers eighteen to twenty-four years of age. ${ }^{22}$ Estimates range up to 200,000-plus adolescent workers suffering job-related injuries and illnesses each year, a staggering number. ${ }^{23}$ Moreover, there is good reason to believe our count is lower than the actual numbers.

Our child labor laws restrict private remedies for youth workers, while placing primary responsibility for enforcement on administrative agencies that consistently fail to enforce even the limited prohibitions under current law. ${ }^{24}$ As an illustrative example, enforcement activity of the Wage and Hour Division (WHD), the lead enforcement agency

Preparation Programs, 95 Am. J. Pub. Health 404, 404 (2005).

22. Center for Disease Control and Prevention, Nonfatal Occupational Injuries and Illnesses Among Workers Treated in Hospital Emergency Departments-United States, 2003, 55 Morbidity \& Mortality Wkly. Rpt. 449, 449-452 (2006) [hereinafter 2003 Nonfatal Occupational Injuries and Illnesses]; Ctrs. for Disease Control and Prevention, Nonfatal Occupational Injuries and Illnesses Among Workers Treated in Hospital Emergency Departments-United States, 2004, 56 Morbidity \& Mortality Wkly. Rpt. 393, 393-397 (2007) [hereinafter 2004 Nonfatal Occupational Injuries and Illnesses]; Natl. Inst. for Occupational Safety and Health, NIOSH Alert: Preventing Deaths, Injuries and Illness of Young Workers, U.S. Dept. of Health \& Human Servs. Ctrs. for Disease Control 2, http://www.cdc.gov/niosh/docs/2003128/pdfs/2003128.pdf (2003) [hereinafter NIOSH Alert].

23. Natl. Inst. for Occupational Safety and Health, Safety and Health Topic:

Young Worker Safety and Health 7 , http://www.cdc.gov/niosh/docs/NIOSHRecsDOLHaz/pdfs/DOL-recomm.pdf (2002) [hereinafter NIOSH 2002 Recommendations]. Work-related illness data is even more difficult to document than injuries because of the long latency period often associated with these pathologies.

24. In stark contrast to minimum wage and maximum hour provisions of the FLSA and most civil rights statutes, federal law gives no private right of action for children injured or killed while working. See e.g., Breitwieser v. KMS Indust., Inc., 467 F.2d 1391, 1392 (5th Cir. 1972); Henderson v. Bear, 948 F.2d 144, 144-146 (Colo. App. 1988). The most effected persons-aggrieved minor employees and their parents-are thus unable to sue as "private attorneys general." Between 1988 and 2008 no employer faced a criminal prosecution for violation of the Act. See generally 29 U.S.C. § 216(a) (2010). Despite the dangers in farm work, in 2006 just twenty-eight of 1,344 federal child labor investigations-2\%-targeted agribusiness. Child Labor Enforcement: Are We Adequately Protecting Our Children? Hearing Before the $H$. Comm. on Educ. and Labor, 110th Cong. (statement of Sally Greenberg, Executive Director, National Consumers League) 5, http://www.nclnet.org/worker-rights/82child-labor/308-ncl-testimony-to-house-on-child-labor-enforcement (2008). In 2005, the number was even lower-just twenty-five. Id. In addition, a "one free bite" rule is in effect; employers may be jailed only after a prior criminal conviction for violation child labor laws. 
at the federal level, has consistently and dramatically declined over the past decade. ${ }^{25}$ WHD's considerable rulemaking powers have likewise atrophied. ${ }^{26}$ Enforcement of state laws is similarly almost nonexistent. $^{27}$

Nor is this a merely a contemporary phenomenon. Historically, restrictions on child labor have always been more symbolic than real. Where youth were cost-effective substitutes for mechanization or adult labor, the FLSA and state statutes had little impact. Child labor statutes have always been riddled with exceptions that frequently overwhelm statutory norms, ${ }^{28}$ with enforcement almost non-existent,

25. See Child Labor Coalition, Protecting Working Children in the United States: The Government's Striking Decline in Child Labor Enforcement Activities 1, http://www.stopchildlabor.org/pressroom/CLC\%20report\%20Sept\%202006.pdf (2006).

26. Despite thirty-eight urgent proposed changes to the existing DOL Hazardous Orders by the National Institute on Occupational Health and Safety (NIOSH) proposed in 2002, see NIOSH 2002 Recommendations, supra n. 23; DOL has, to date, adopted only four. DOL has also ignored all proposals to change the agricultural Hazardous Occupation Orders. See id.; Child Labor Regulations, Orders and Statements of Interpretation; Child Labor Violations-Civil Money Penalties, 69 Fed. Reg. 75382 (Dec. 16, 2004).

27. Most states lack the resources needed to effectively enforce child labor laws. The number of enforcement officers is dwindling and there are few child labor investigations.

\begin{tabular}{|l|l|l|l|}
\hline & $2000^{*}$ & $2003^{* *}$ & $2004^{* * *}$ \\
\hline $\begin{array}{l}\text { Total number of state labor } \\
\text { inspectors devoted } \\
\text { exclusively to child labor }\end{array}$ & 40 & 28 & 19 \\
\hline
\end{tabular}

*In 2000, 39 states reported their statistics to the CLC.

**In 2003, 39 states reported their statistics to the CLC.

***In 2004, 32 states reported their statistics to the CLC.

Information gathered from the Child Labor Coalition, Child Labor State Surveys, http://www.stopchildlabor.org/USchildlabor/ (accessed Jan. 29, 2011) [hereinafter 2004 CLC State Survey]. In 2004, only five states conducted inspections targeting child labor compliance in agriculture; a mere three states found any child labor violations-with a total of nine minors in two states, while the third could not provide figures. Id. (including a table that indicates each responding state's statistics).

28. The Keating-Owen Act of 1916, for example, affected less than $10 \%$ of all working children. See infra nn. 103-109 and accompanying text. Subsequent legislation followed the same pattern. Restrictions on the employment of youths in the NRA codes followed the principles of the Keating-Owen Act and applied to only one out of every six employed youngsters between the ages of ten and sixteen reported by the 1930 Census to 
either in court or administratively. ${ }^{29}$

As a result, American law de facto permits and even prods adolescents to work, either full- or part-time. Unfortunately, today's workplace encourages

[y]oung people [to] perform tasks and use skills ... that few perform or use again in work settings after they cease to be adolescents... [These jobs provide] little meaningful contact with adults who have a stake in their socialization for the future ... [E]conomic rewards ... typically are used for ... records, movies, designer clothing, fast food, alcohol, drugs - and not for long-term "adult" investments, such as college, or for increasing the adolescent's ability to establish an independent household. ${ }^{30}$

In addition, the law provides adolescents extraordinary freedom to make independent decisions on work and school. As a matter of federal law, no parental consent or even notice is required before a child may work. In many states, children may withdraw from school without parental notice or consent once a minimum age is attached. ${ }^{31}$

be working. Jeremy P. Felt, The Child Labor Provisions of the Fair Labor Standards Act, 11 Lab. Hist. 467, 473 (1970). When federal child labor regulation was finally upheld in the FLSA, contemporary estimates indicated only about $30,000-50,000$ employed children would be effected in nonagricultural occupations, but about 850,000 children fifteen years of age and younger were gainfully employed. Id. at 477 . Exclusions from the FLSA, e.g., work in retail and street trades or in agriculture, allowed children to fill niches in the economy where it was, and is, profitable to use them.

29. See supra $\mathrm{nn}$. 24-27 and accompanying text.

30. Greenberger, supra n. 12 , at 88-89.

31. In twenty-two states, students may leave school at sixteen without parental consent. See e.g., Ala. Code § 16-28-3 (2011). Astonishingly, a mere twenty-one states limit children under the age of sixteen to three hours of work per day during the school year, see e.g. Ala. Code $\$ 25-8-36$ (2011); Ariz. Rev. Stat. §23-233 (2011); Cal. Lab. Code § 1391(a)(2) (2010); and only thirty-eight jurisdictions require parental consent for under-sixteens to work. U.S. Dept. of Lab., Employment/Age Certification, http://www.dol.gov/whd/state/certification.htm (accessed Jan. 29, 2010). Only sixteen states mandate parental consent for sixteen-and seventeen-yearold adolescents to work, three of which only mandate consent during school hours. Id. Forty-four states allow children aged sixteen and seventeen to work forty or more hours during weeks while school is in session. U.S. Dept. of Lab., Wage and Hour Division, Selected Child State Labor Standards, http://www.dol.gov/whd/state/state.htm (accessed Jan. 29, 2010). Thirty states 
My purpose here is to analyze how American law arrived at this laissez-faire position regarding child labor that creates such overwhelmingly negative results. This Article proceeds as follows: Part Two briefly outlines the history of child labor in the United States and early state attempts to regulate its worst abuses. Part Three describes efforts until the 1920 s by the federal government to limit exploitation of youth workers. This Part details the previously untold factual and legal history of several important United States Supreme Court cases dealing with child labor, especially the famous decision in Hammer v. Dagenhart. ${ }^{32}$ Unearthed from the case record found at the Library of Congress, the story of Hammer, and its follow up cases, illustrates the litigation strategy of powerful mill owners in North Carolina before a hand-picked conservative federal district court judge and a Supreme Court determined to block efforts to limit business immunity.

Part Four follows this history to the 1920s and 1930s, detailing the struggle to pass a new constitutional amendment and statutes restricting child labor. With Locknerism demolished by the Great Depression of the 1930s, the passage of the FLSA and its subsequent legitimation by a reformed Supreme Court seemed to spell victory against employer use of child labor. This victory was, in fact, pyrrhic. The weaknesses of the FLSA resulted in the continuation of youth employment. These statutory deficiencies were the outcome of a toxic combination of factors: profits from cheap labor, entrenched and powerful economic interests, and racism. This explanation is most dramatically illustrated in the exclusion of agricultural workers, including children, from coverage by the FLSA.

\section{History OF CHILD LABOR REGULATION IN THE UNITED STATES}

A. The Formative Period and Subsequent Industrialization

As with many economic and social issues, the roots of American child labor are found in England. The crowded English cities in the sixteenth and seventeenth centuries were full of crime and poverty. ${ }^{33}$

do not even require work or age permits for youths aged sixteen or seventeen. U.S. Dept. of Lab., Employment/Age Certification, http://www.dol.gov/whd/state/certification.htm (accessed Jan. 29, 2010).

32. 247 U.S. 251, 251 (1918).

33. Marvin Ventrell, The Practice of Law for Children, 28 Hamline J. Pub. L. \& 
In the eyes of the British ruling class much of this was created by idleness, particularly of children. ${ }^{34}$ The over-arching principles of the Elizabethan Poor Relief Act of $1601^{35}$ dictated that blood relatives were the primary source of support for family members but local governmental units were responsible for those unable to sustain themselves with private resources. ${ }^{36}$ Public bodies were reluctant, however, to spend money for social welfare. As a result, the poor, including impoverished children, were often "transported" to the developing colonies in the New World. ${ }^{37}$ A 1627 letter, for example, notes "there are many ships going to Virginia, and with them fourteen or fifteen hundred children, "mostly paupers.",38

By the late 1700s there was active promotion of the employment of children in the quickly-developing cotton industry, which brought the industrial revolution to the United States. ${ }^{39}$ By 1816, New England mills employed 100,000 workers, of whom 24,000 were "boys under seventeen" and 66,000 "women and girls." 40 Workers in these by now large industrial factories were often employed through a "family wage

Policy 75, 79 (2006).

34. Catherine G. Trinkley, Child Labor in America: An Historical Analysis, 13 In Pub. Int. 59, 63 (1993).

35. 43 Eliz. Ch. 2, § 7 (Eng. 1601).

36. The Elizabethan Poor Relief Act of 1601 mandated that father and grandfather, the mother and the grandmother, and the children of every poor, old, blind, lame, and impotent person support that relative to the extent of his or her ability. 43 Eliz. Ch. 2, \$6 (Eng. 1601); see also Robin M. Jacobson, Americana Healthcare Ctr. v. Randal: The Renaissance of Filial Responsibility, 40 S.D. L. Rev. 518, 527 (1995).

37. This would "render [children] useful members of society" and lessen the need for the community to support families while husbands were away at sea for long periods of time. Elizabeth Lewis Otey, The Beginnings of Child Labor Legislation in Certain States 11 (Amo Press 1974).

38. Trinkley, supra n. 34, at 64.

39. In the 1790 s, Samuel Slater and his New England partners began a factory that combined all stages of manufacture from raw cotton to yarn in one structure. The first employees of the factory were nine boys from poor families in the vicinity. In contrast to earlier practice these children were factory laborers, rather than apprentices. By 1801 , the number of children increased to one hundred ranging in age from four to ten. The children became the "little fingers ... of the gigantic automatons of laborsaving machinery." U.S. Bureau of Lab., Charles Patrick Neill, Report on Condition of Women and Child Wage-Earners in the United States 48 (Govt. Printing Off. 1910).

40. American State Papers, Protection to the Manufacturers of Cotton Fabrics, 3 Finance 83, 14th Cong., 1st Sess. (Feb. 13, 1816). 
system," in which all members worked and received one lump sum. ${ }^{41}$ Every member of the family above age seven worked in the factory from sunrise to sunset, six days a week. Children's wages were calculated and graded according to age. ${ }^{42}$

Nor was this youth work aberrational. Throughout the colonies children worked in various capacities. "Bound out" children were taken in by strangers with the expectation that children would work. ${ }^{43}$ Indentured service was a practice inherited from England, based on the legal presumption that the child owed service to his or her parent who could assign that service to others. ${ }^{44}$ Apprenticeship involved a contract between a parent and another adult promising to provide practical training in a trade or craft in exchange for service by the child. These ubiquitous arrangements were often more exploitative than protective of the well-being of children. Some parents and other custodians even advertised the availability of their children to perform labor. ${ }^{45}$

In sum, children were an integral part of the production process in the early United States. The sanctity of work and fear of idleness were the accepted rationales for these employment relationships. ${ }^{46}$ Children's working was accepted not only to increase production at minimum expense but also to control poor and potentially criminal elements of society.

As population and industrialization grew, particularly in the second half of the nineteenth century, the total number of young workers increased dramatically. In the thirty years between 1870 ,

41. In New England rural families tended to move to the mill and lived in a community built and owned by the company. Hugh D. Hindman, Child Labor: An American History 35-36 (M.E. Sharpe, Inc. 2002).

42. Thomas Dublin, Women At Work: The Transformation of Work and Community in Lowell, Massachusetts, 1826-1860 173 (2d ed. Columbia U. Press 1979). A male-headed family with three working children received approximately $65 \%$ of the annual family income from the children's labor. Id.

43. David Ray Papke, Pondering Past Purposes: A Critical History of American Adoption Law, 102 W. Va. L. Rev. 459, 460 (1999).

44. This legal concept was to provide a key element in Hammer v. Dagenhart. See infra nn. 177-179 and accompanying text. Michael Grossberg, Governing the Hearth: Law and the Family in Nineteenth Century America 259 (U. N.C. Press 1985).

45. Papke, supra n. 43, at 461.

46. Robert Bremner et al., Children and Youth in America: A Documentary History, Vol. I: 1600-1865 147 (Am. Public Health Assn. 1970) [hereinafter Children and Youth Vol. I]. 
when occupational information about youths ten through fourteen was first collected, and 1900, the Census reveals a startling rise in both the number and proportion of children entering the labor force. By 1900 , six percent of children gainfully employed were between ten and fifteen years, and there were officially more than 1.75 million youth workers in America. ${ }^{47}$ Children in the post-Civil War South were particularly encouraged to work due to the loss of men in battle and the desire to provide cheap labor for the new textile mills beginning in the South. One-third of the workforce in southern textile mills was between ten and thirteen years of age. ${ }^{48}$

Another factor contributing to child labor was massive immigration. Between 1860 and 1890 , over ten million immigrants arrived in the United States. ${ }^{49}$ They joined the considerable number of the poor already here. These families faced poverty and chronic underemployment. ${ }^{50}$ Parents commonly sent their children to work ${ }^{51}$ and often opposed child labor reform because of the desperate need for additional income. ${ }^{52}$ Children's work in nineteenth and twentieth century America was parental property, ${ }^{53}$ stemming from the rule that

47. A total of $1,750,178$ children were employed, an increase of one million children since 1870. See William Lerner, Historical Statistics of the United States: Colonial Times to 1970, U.S. Dept. of Commerce: Bureau of the Census 75-84 (1975).

48. Employment of children in Southern states in industry became more common in the late 1800 s as the region's textile industry expanded. By 1900, more children worked in southern mills than in any other part of the United States. By 1906, southern mills employed an estimated 60,000 children under the age of fourteen. See Stephen Wood, Constitutional Politics in the Progressive Era 8 (U. Chi. Press 1968). These figures did not include the many children under the age of ten who were known to be at work. Id.

49. U.S. Citizenship and Immig. Servs., 2002 Yearbook of Immigration Statistics 11, http://www.dhs.gov/xlibrary/assets/statistics/yearbook/2002/ IMM2002.pdf (accessed Jan. 29, 2011).

50. See e.g., John Modell, Changing Risks, Changing Adaptations: American Families in the Nineteenth and Twentieth Centuries, in Kin and Communities: Families in America 119, 128 (Allan J. Lichtman \& Joan R. Challinor eds., Smithsonian Press 1979) (describing child labor in working-class families "as an attempt to pool risks in what was experienced as a very uncertain world").

51. William J. Cooper, Jr. \& Thomas E. Terrill, The American South: A History, Vol. 2, 617-619 (Rowman \& Littlefield Publishers, Inc. 2009).

52. Viviana A. Zelizer, Pricing the Priceless Child: The Changing Social Value of Children 69-70 (Basic Books 1985).

53. Barbara Bennett Woodhouse, Who Owns the Child?: Myer and Pierce and the Child as Property, 33 Wm. \& Mary L. Rev. 995, 1059-1061 (1992). 
parents were legally entitled to their offspring's services. ${ }^{54}$ At the end of the nineteenth century approximately 400,000 children, five to eighteen years of age, were employed in New York alone. ${ }^{55}$

Although the immigrant population remained largely concentrated in urban areas, work by children in agrarian areas was also frequently an economic necessity and, indeed, was seen as essential to a child's upbringing. From the beginning, the prevailing American ethos was that agricultural labor provided training for adulthood and independence. ${ }^{56}$ After the Civil War, however, population increasingly migrated from rural communities to larger industrial cities. ${ }^{57}$ From 1900 to 1920 , the urban population in the United States grew by $80 \%$, while rural populations correspondingly declined. ${ }^{58}$

The short- and long-term hazards of work in these industrial workplaces were often great. Unhealthy and dangerous working

54. Homer H. Clark, The Law of Domestic Relations in the United States 314 (2d ed., West 1988); see Singer v. Brookman, 578 N.E.2d 1, 6 (Ill. App. 1991); Porter v. Powell, 44 N.W. 295, 296 (Iowa 1890); Dembinski's Case, 120 N.E. 856, 857 (Mass. 1918); Rohm v. Stroud, 194 N.W.2d 307, 308 (Mich. 1972); Am. Prods. Co. v. Villwock, 109 P.2d 570, 579 (Wash. 1941). As one state Supreme Court Justice asserted in 1888, "[i]t is a rule as old as the common law that the father is entitled to the custody and control of his minor children, and to receive their earnings." Eustice v. Plymouth Coal Co., 13 A. 975, $976(\mathrm{~Pa} .1888)$. The right of parents to children's services, however, correlated to the parent's obligation to support the child. Covey $v$. Eppes, 153 So. 2d 3, 4 (Fla. 1963); Beaudoin v. Beaudoin, 386 A.2d 1261, 1263 (N.H. 1978). This right is statutory today in many states. See e.g., Cal. Fam. Code $\S 7503$ (West 2011) ("The employer of a minor shall pay the earnings of the minor to the minor until the parent or guardian entitled to the earnings gives the employer notice that the parent or guardian claims the earnings."); Mich. Comp. Laws Ann. $§ 722.2$ (West 2011); N.J. Stat. Ann. § 9:1-1 (West 2011); N.M. Stat. Ann. § 32A-21-5 (West 2010); R.I. Gen. Laws § 33-15.1-1 (West 2011).

55. Jeremy P. Felt, Hostages of Fortune 36 (Syracuse U. Press 1965).

56. See infra nn. 359-362 and accompanying text; see also $41 \mathrm{st}$ Cong. Rec. 1552 (1907) (statement of Sen. Beveridge):

This bill does not strike at the employment of children engaged in agriculture. I do not for a moment pretend that working children on the farm is bad for them. I think it is the universal experience that where children are employed within their strength and in the open air there can be no better training.

Id.

57. Wood, supra $\mathrm{n} .48$, at $1-2$.

58. Id. 
conditions abounded. ${ }^{59}$ Workers were obliged to keep pace with mechanized production. Women and youth were especially vulnerable. $^{60}$

It is a sorry but indisputable fact that where children are employed, the most unhealthful work is generally given them. In the spinning and carding rooms of cotton and woolen mills, where large numbers of children are employed, clouds of lint-dust fill the lungs and menace the health ...In bottle factories and other branches of glass manufacture, the atmosphere is constantly charged with microscopic particles of glass. In the wood-working industries, such as the manufacture of cheap furniture and wooden boxes, and packing cases, the air is laden with fine sawdust. Children employed in soap and soap-powder factories work, many of them, in clouds of alkaline dust which inflames the eyelids and nostrils ...In the coalmines the breaker boys breathe air that is heavy and thick with particles of coal, and their lungs become black in consequence. ${ }^{61}$

Children as young as eight worked in the mines, which then, as now, were one of the most dangerous places to work. ${ }^{62}$ While

59. See e.g., Edwin Markham et al., Children in Bondage 63-65 (Hearst's Intl. Lib. Co. 1914):

In a Pennsylvania establishment, where the temperature on the outside was 88 degrees, the temperature at the point where the snap-up rubs off the excess glass was 100 degrees; in front of the glory-hole it was 140 degrees...The speed rate of the snapping-up boy is fixed by the output of the shop, and in case of such small wares as one ounce and under he must work with great rapidity....In one factory,...the distance from bench to oven was one hundred feet, and the carry-in boys made seventy-two trips in an hour.

Id.

60. See generally Inland Steel Co. v. Yedinak, 87 N.E. 229, 229-236 (Ind. 1909) (thirteen-year old's legs crushed by carload of iron after working eleven hours and falling asleep); Sitts v. Waiontha Knitting Co., Inc., 87 N.Y.S. 911, 911 (1904) (fifteenyear-old severely injured in rollers of knitting machine); Marino v. Lehmaier, 66 N.E. $572,572-573$ (N.Y. 1903) (thirteen-year-old's fingers cut off in printing press).

61. John Spargo, The Bitter Cry of the Children 175-80 (1906), reprinted in Robert Bremner et al., Children and Youth in America: A Documentary History, Vol. II: 1868-1932) [hereinafter Children and Youth Vol. II].

62. Louis Hine, a sociologist and photographer working for the National Child Labor Committee, noted: "then the pieces (in the coal mines of Pennsylvania) rattled down through long chutes at which the breaker boys 
information gathering was difficult, it is believed that young boys under the age of sixteen had twice as many accidents as adult workers, while girls had three times as many accidents as adult women. ${ }^{63}$

The best known example of this physical carnage is the New York Triangle Shirt Waist factory fire in March of 1911. One hundred forty-six garment workers, many as young as fourteen, died in the fire. Twelve- and thirteen-year-olds were also known to be working fourteen-hour shifts at the factory. ${ }^{64}$ Death and injury to child workers have been a consistent result of the employment of young people in America to the present day. ${ }^{65}$

As child labor increased in number and intensity during the nineteenth century, concerns concomitantly arose about the effect of this employment on families, children and society. Compulsory education was increasingly seen as the antidote to exploitative child labor. Early compulsory school attendance laws, however, were

sat. These boys picked out the pieces of slate and stone that cannot burn. It's like sitting in a coal bin all day long, except that the coals is always moving and clattering and cuts the fingers."

Little Comrades Who Toil, 3 Child Lab. Bull. 72 (Natl. Child Lab. Comm. 1914). In 1902, a minister in Pennsylvania reported " 1 have seen boys going to the breaker that did not seem really able to carry their dinner pail." Alan Derickson, Making Human Junk: Child Labor as an Issue in the Progressive Era, 82 Am. J. Pub. Health 1280, 1281 (1992).

63. Julie Novkov, Historicizing the Figure of the Child in Legal Discourse: The Battle Over the Regulation of Child Labor, 44 Am. J. Leg. Hist. 369 (2000) (quoting Edwin Markham, Ben Lindsey \& George Creel, Children in Bondage 158-59 (Hearst's Intl. Lib. Co. 1914)).

64. For a detailed description of the deplorable conditions of the factory, the fire and ensuing trial, visit Douglas Linder, Famous Trials,

http://www.law.umkc.edu/faculty/projects/FTrials/triangle/trianglefire.html (accessed Jan. 29, 2011).

65. See The Natl. Inst. for Occupational Safety and Health, Recommendations from the NIOSH Child Labor Working Team, http://www.cdc.gov/niosh/docs/97-143/ (accessed Jan. 29, 2011). Fatalities of working youth are far too common, and they have the highest rates of injury of any age group. Schulte, supra n. 21, at 404-411. Work-related injury rates for juvenile workers have consistently been found to be between $60 \%-70 \%$ higher than the rates for workers of all ages and second only to rates for workers eighteen to twenty-four years of age. 2003 Nonfatal Occupational Injuries and Illnesses, supra n. 22; 2004 Nonfatal Occupational Injuries and Illnesses, supra n. 22; NIOSH Alert, supra n. 22. Estimates range up to 200,000-plus adolescent workers suffering job-related injuries and illnesses each year, a staggering number. NIOSH 2002 Recommendations, supra n. 23, at 7. Work-related illness data is even more difficult to document than injuries because of the long latency period often associated with these pathologies. 
limited in scope and lacked enforcement mechanisms. ${ }^{66}$ Advocacy of legal restrictions on youth employment and of mandatory school attendance laws were complementary, and the two movements developed simultaneously between 1830 and $1930 .^{67}$ In the mid1800 s, a few states also began setting minimum age requirements to work $^{68}$ and limiting working hours. ${ }^{69}$ These early child labor prohibitions, however, were poorly enforced and rarely followed. ${ }^{70}$

\section{B. Reform Efforts and the Progressive Era}

Momentum for child labor regulation increased dramatically in the late-nineteenth and early-twentieth centuries, however, as huge numbers of children entered the labor market. ${ }^{71}$ Beginning with the

66. While many states in the nineteenth century required some compulsory school attendance, they failed to create effective enforcement bodies or to fund regulatory agencies to ensure compliance. Additionally the geography of many of the states prevented effective compliance, as did the lack of an accurate census. See Michael S. Katz, A History of Compulsory Education Laws 18-21 (Phi Delta Kappa 1976). Age was difficult to substantiate from parents and school records were notoriously inaccurate. Trinkley, supra n. 34, at 75.

67. Wayne J. Urban \& Jennings L. Wagoner, Jr., American Education: A History 151-173 (4th ed., Routledge 1999).

68. Children and Youth vol. I, supra n. 40, at 621. Most minimum ages ranged from nine to thirteen years, but since proof of age was not required in any of the early minimum age statutes, enforcement was practically impossible. Id. at 627. Additionally, a number of these laws allowed younger children in poor families to work under "hardship exemptions." Hindman, supra n. 41, at 62.

69. Most of the state laws regulating hours in the mid-1800s limited minor workers to ten hours per day. Children and Youth Vol. I, supra n. 40, at 628. Many hour limitation laws, however, contained a "special contract" provision allowing employees to work longer hours. Hindman, supra n. 41, at 62. Another method to restrict a young person's employment, of course, was to mandate school attendance for a portion of the year. Studies indicated that labor at a young age hurt a child's development and schooling improved it, contributing to the side by side development of the movements. See William Aikman \& Lawrence Kotin, Legal Foundations of Compulsory School Attendance 45-53 (Kennikat Press 1980).

70. Felt, supra $\mathrm{n}$. 55, at 6, 17-37 (Under-age children were hidden by factory owners or by families when inspectors did visit workplaces; look-outs scouted the approach of inspectors and if violations of the law were found, employers argued that the children's age had been misrepresented to them or the youths were simply visitors).

71. As in many social welfare issues, the United States lagged behind Europe. The first law regulating child labor was approved in Prussia in 1839; France followed in 1841. Paul Perigord, The International Labor Organization: A Study of Labor and Capital in Cooperation 39 (D. Appleton 1926); Carlos Crespo, When Labor Went Global: The Road to the International Labor Organization, 37 Rev. Jur. U.P.R. 129, 
development of the Progressive Movement in the 1890s, school systems grew in size and complexity, new techniques of bureaucratic control emerged and school officials developed more sophisticated techniques to check on, and enforce, school attendance. ${ }^{72} \mathrm{An}$ ideological component also surfaced; public schools were to be the vehicle to "Americanize" children, particularly those of immigrant parents. $^{73}$

The Progressive Movement in the late-nineteenth and earlytwentieth centuries was comprised of religious organizations, women's groups, trade unions and others advocating on behalf of a wide variety of reforms. ${ }^{74}$ In fact, "Progressivism" was more a set of ideas than a disciplined political movement. The legislative agenda included restrictions upon child labor, enactment and enforcement of compulsory school attendance laws, criminalizing abandonment and abuse of children, ${ }^{75}$ and creating new Juvenile courts to deal with "delinquent" acts. ${ }^{76}$ Child welfare became the focus of the newly developing social work profession. ${ }^{77}$

The Progressives had a healthy respect for the power of positive law and, as historian David J. Rothman notes, "were not afraid to

132 (2002).

72. See generally Kathy Emery, Alternative Schools: Diverted But Not Defeated, Paper submitted to Qualification Committee at UC Davis, California, http://www.educationanddemocracy.org/Emery/Emery_AltSchoolsPaper.htm (July 2000).

73. See Gwendolyn Mink, The Wages of Motherhood: Inequality in the Welfare State, 1917-1942 77 (Cornell U. Press 1995).

74. See generally Wood, supra $\mathrm{n}$. 48. The idea of the state as an agency of social and economic reform and control was part of Progressive ideology.

75. There is much contemporary debate today about whether the Progressive Era's child-saving initiatives were more rescue or exploitation. "Orphan trains," carrying poor children from large, mainly Eastern, cities were sent to the Midwest to live and work with farm families. Critics claim that this transfer removed children from parents without valid consent and disregarded the best interests of the child. See generally Marilyn Irvin Holt, The Orphan Trains: Placing Out in America 41-79 (U. Neb. Press 1994); David J. Rothman, Conscience and Convenience: The Asylum and Its Alternatives in Progressive America 215 (Little Brown 1980); Papke, supra n. 43 (discussing Progressive movement).

76. Chicago established the first juvenile court in 1899. By the end of World War I only three states did not have juvenile courts along with diversion of youth offenders from jail to local youth homes and other institutions. David S. Tanenhaus, Juvenile Justice in the Making 24 (Oxford U. Press 2004).

77. Grossberg, supra n. 44, at 278-280. 
introduce the coercive force of law" in the service of their goals. ${ }^{78}$ In contradistinction to the benign bucolic image of children acquiring skills and education through healthful farm labor, ${ }^{79}$ the Progressives recharacterized child labor as exploitative of children and destructive to society as a whole. ${ }^{80}$ As a remedy, they forcefully advocated stronger and more frequent use of the state's parens patriae power. ${ }^{81}$ State actors were to rescue children from unsatisfactory care by parents and from forces, particularly economic, which could deprive youths of the schooling and health necessary to become productive adult citizens. ${ }^{82}$

Opposition to youth employment began to build. The growing Union movement supported child labor restrictions, partly for humanitarian reasons and partly for economic factors relating to adult unemployment and the downward drag on wages of masses of child workers. ${ }^{83}$ The National Child Labor Committee was formed in 1904

78. Rothman, supra n. 75, at 207.

79. See infra nn. 359-362 and accompanying text.

80. This was the era of famous urban reformers like Florence Kelly, Jane Adams, Jacob Riis, and many others. See generally David E. Kyvig, Explicit and Authentic Acts: Amending the U.S. Constitution, 1776-1995 255-261 (U. Press of Kan. 1996).

81. The "parens patriae" power of the state to protect the child's health, safety and welfare was now used to charge parents with abuse and neglect. This legal concept had been present in Anglo-American law for centuries. The Elizabethan Poor Laws authorized governmental removal of children from parents and outsourcing them as apprentices. Massachusetts's records show children removed from homes already in the seventeenth century and in the eighteenth century in Virginia. Ventrell, supra $\mathrm{n}$. 33, at 79. In the nineteenth century, the parens patriae doctrine was a familiar theme in state court decisions. See e.g., Fletcher v. People, 52 Ill. 395, 397 (1869); Ex Parte Crouse, 4 Whart. 9, 11-12 (Pa. 1839). By 1905, the Pennsylvania Supreme Court noted:

Every statute which is designed to give protection, care and training to children, as a needed substitute for parental authority ... is but a recognition of the duty of the state as the legitimate guardian and protector of children when other guardianship fails.

Cmmw. v. Fischer, 213 Pa. 48, 56-57 (1905).

82. "Ignorant and untaught, deprived of childhood and of the benefits of consecutive school life, the children in the canneries show little promise of developing into citizens more valuable to the state than their immigrant parents." Pauline Goldmark, Do Children Work in Canneries 10 (Consumer's League 1910), quoted in Novkov, supra n. 63, at 381 .

83. "It is perhaps unnecessary to mention the obvious fact that the child worker is in competition with the adult and drags down his wages." Lillian Wald, The House on Henry Street 146 (Henry \& Hold Co. 1971). Abolition of child labor was included in the constitutions of the Knights of Labor and the Federation of Organized Trade Unions, which later became the American Federation of Labor (AFL). Hindman, supra 
and became a catalytic agent for these legislative efforts. ${ }^{84}$ Images of children working in mines, canneries and textile mills, most forcefully portrayed in the photo-journalistic work of Lewis Hine, fostered a favorable public climate for restrictions on child labor. ${ }^{85}$ By 1906 , forty-two states had some type of child labor legislation. ${ }^{86}$

These statutory developments were occurring during the Lochner ${ }^{87}$ era, a time when federal courts were particularly resistant to legislation limiting the prevailing "laissez faire" economic theory. Child labor restrictions were, of course, promptly challenged as unconstitutional violations of "liberty of contract" and government interference with the parent-child relationship. While the United States Supreme Court and the federal courts were hospitable to a variety of these constitutional claims, state courts were far less sympathetic to these same arguments. State courts tended to uphold protection of working children as a lawful exercise of the state's parens patriae power. For example, in Inland Steel Co. v. Yedinak, ${ }^{88}$ a thirteen-yearold was employed in the steel mill working six days per week and twelve to fourteen hours per day. When his leg was severed in an industrial accident he sued for damages under negligence theory, premised upon violation of the Indiana law that prohibited under sixteen-year-olds working more than sixty hours per week or ten hours per day. ${ }^{89}$ The steel mill argued that the statute violated the Fourteenth

n. 41, at 49. As a young labor leader in New York, Samuel Gompers pushed for regulation of child labor, and later, as President of the AFL, he consistently supported child labor reform. Id.; see Felt, supra n. 55, at 10-13, 60, 196-197; Samuel Gompers, Labor and the Common Welfare 129 (EP Dutton \& Co. 1919).

84. Walter Trattner, Crusade for the Children: A History of the National Child Labor Committee and Child Labor Reform in America 35 (Quadrangle Books 1970).

85. See Kyvig, supra n. 80, at 259-261.

86. 41 Cong. Rec. S1809-1810 (1907).

87. Lochner v. New York, 198 U.S. 45, 52 (1905) (invalidating New York law limiting bakers to sixty-hour work weeks). During this period of time, approximately 1890-1937, the federal judiciary and particularly the United States Supreme Court articulated a theory of "liberty" under the Fifth and Fourteenth Amendments that included a "freedom" to contract. It is estimated that more than 175 state laws were found unconstitutional in this period. Erwin Chemerinsky, Constitutional Law: Principles and Policies 616 (3d ed., Aspen 2006). At the same time, the Court was concomitantly striking down federal statutes as beyond Congress' power under the Commerce Clause or as violating the Tenth Amendment. See Hammer v. Dagenhart, 247 U.S. 268, 277 (1918) (holding unconstitutional federal statute limiting child labor).

88. Inland Steel Co. v. Yedinak, 87 N.E. 229, 231 (Ind. 1909).

89. Id. at 232. 
Amendment, but the Indiana Supreme Court responded:

Children under 16 years of age are wards of the state, and are pre-eminently fit subjects for the protecting care of its police power....The employment of children of tender years in mills and factories not only endangers their lives and limbs, but hinders and dwarfs their growth and development physically, mentally, and morally. Defendant argues "it deprives the defendant of liberty and of its property without due process of law" and equal protection ...We think it quite obvious that the point is not well taken..$^{90}$

Numerous other state courts routinely upheld child labor protective measures. ${ }^{91}$

Yet these state legislative and court victories rested on an unstable foundation. The actual effect on the employment of children was often negligible. Lack of governmental enforcement of child labor restrictions and compulsory school attendance laws was widespread throughout the United States. ${ }^{92}$ The South was particularly resistant. For example, in North Carolina, site of the coming legal battle on federal restrictions of child labor, efforts to restrict the minimum age of youth workers faced opposition from mill owners employing children as young as nine. The destitute parents of these youth workers were often likewise opposed. ${ }^{93}$ It took until 1904 to limit child labor in

90. Yedinak, 87 N.E. at 234-235; Fitzgerald v. Intl Flax Twine Co., 104 Minn. 138,145 (1908).

91. See e.g., Ex Parte Spencer, 86 P. 896, 896-897 (Cal. 1906); Fitzgerald v. Intl Flax Twine Co., 104 Minn 138, 146 (1908); Bryant v. Skillman Hardware Co., 76 N.J.L. 45, 45-46 (1908); People v. Taylor, 192 N.Y. 398, 399-400 (1908); State v. Shorey, 86 P. 881, 881-882 (Ore. 1906).

92. Violators were rarely fined or otherwise punished, and many parents were unaware of any restrictions on employing children. Children and Youth, Vol. I, supra n. 40, at 628-630. And, in any event, poor parents desperately needed the income from their children's work. While southern manufacturing states were setting minimum age standards for child labor, none provided means of enforcement of these statutes. In North Carolina, for example, the Bureau of Labor Commissioner could only collect information from manufacturers through questionnaires, not inspections. To insist upon plant visits would question the honesty of the plant owner. Early efforts in North Carolina to determine the number of children working in factories consisted of mailed inquiries to factory owners, who often failed to answer. Elizabeth H. Davidson, Child Labor Legislation in the Southern Textile States 102, 126 (U. N.C. Press 1939).

93. Davidson, supra n. 92, at 118,121 . It was estimated that over 10,000 children under age twelve were working in textile mills in South Carolina in 1901. In 1904 the 
North Carolina to over twelve-year-olds and a maximum work week of sixty-six hours. ${ }^{94}$ Even then, younger children classified as apprentices were excepted from these limits. ${ }^{95}$ Not until 1918 were children aged ten to fourteen required to attend school for the entire school term and restricted from the most dangerous worksites. ${ }^{96}$ Southern mill owners successfully harnessed regional resentments and fears to block labor law change. ${ }^{97}$

Reform efforts varied dramatically across the country. Many states had little or no budget for inspections and few effective penalties for noncompliance. ${ }^{98}$ States seeking to attract capital and industry and to increase industrial production had incentives to have lax or no legislation on youth employment, creating a classic "race to the bottom." In 1907, Senator Albert Beveridge of Indiana characterized the situation as follows:

Here is an abstract of the state laws upon the subject of child labor. There are not six of them alike. Some have no childlabor laws at all; others are worse than any laws, because they are pretenses at labor legislation which make the people and the country think that something has been done, when, as a matter of fact, nothing has been done, and the ruin that went on before without the sanction of the law continues under the sanction of the law. ${ }^{99}$

Federal action was the only realistic way to effectively combat child labor.

\section{ACTION AT THE FEDERAL LEVEL}

The first federal legislative action came in 1906, with a proposal by Indiana Senator Albert Beveridge and Representative Herbert Parson to prohibit interstate shipments from factories and mines

North Carolina legislature agreed to set the age of twelve as the minimum age of child manufacturing workers.

94. Id. at 120 .

95. Id. at 251 .

96. Id. at 76 .

97. Child labor opponents were labeled "Yankees" and their proposed legislation as "Yankee doings" in an attempt to use Civil War memories to block reform. Id. at 121.

98. Novkov, supra n. 63, at 373.

99. 41 Cong. Rec. 1808 (1907). 
employing children under fourteen. ${ }^{100}$ As a progressive reformer and police commissioner in New York City, Theodore Roosevelt had supported limits on child labor, but as President in 1906 he scuttled the Beveridge Bill, substituting a federal study of female and child labor in its place. ${ }^{101}$ Ultimately, the study resulted in at least twenty volumes of data and text demonstrating the health, educational and other problems associated with employment of these workers. ${ }^{102}$ In 1912, reformers succeeded in passing legislation creating the Children's Bureau, ${ }^{103}$ the first federal agency to deal with children. The Bureau acted as a research organization on youth issues and developed into an advocacy group for reform.

The first substantive federal regulation of child labor came with passage of the Keating-Owen Act in 1916. ${ }^{104}$ The Act banned the entry into interstate commerce of the "products" of mines, manufacturers or other producers who had employed child labor in defined categories; ${ }^{105}$ children under sixteen working in mines and quarries and under fourteen working in factories and some other worksites were barred from employment. The statute also limited youth between fourteen and sixteen to an eight-hour day and a fortyeight-hour week. ${ }^{106}$

The Act was a symbolic victory, but practically ineffective. Foreshadowing later federal enactments, many working childrenespecially in agriculture and other worksites-were omitted from coverage. Owen Lovejoy, chair of the National Child Labor Coalition (NCLC) estimated in 1917 that perhaps 150,000 working children were

100. John Braeman, Alfred J. Beveridge and the First National Child Labor Bill, 60 Ind. Mag of History 1, 19-20 (1964).

101. Pub. L. No. 59-41, $\S 432,34$ Stat. 866 (1907) (authorized the Secretary of Commerce and Labor to "investigate and report on the industrial, social, moral, educational, and physical condition of women and child workers in the United States").

102. 46 Cong. Rec. 1806 (1911).

103. Pub. L. No. 62-116, § 73, 37 Stat. 79 (1912).

104. Pub. L. No. $64-249, \S 432,39$ Stat. 675 (1916). The bill passed the House by a vote of $237-45$, but had been blocked for almost one year in the Senate by North Carolina Senator Lee Overman; Trattner, supra n. 84, at 132.

105. 39 Stat. at 675 .

106. Id. Criminal penalties attached to violations of the Act. Id. (first conviction to be punished by a fine of not more than $\$ 200$ and each subsequent conviction to be punished by a fine of not more than $\$ 1000$ or by imprisonment of not more than three months or both). 
affected by the statute, while $1,850,000$ were not. ${ }^{107}$ No legal remedies were provided to workers themselves. But perhaps the most salient reason for the Keating-Owen Act's failure was the abject poverty of millions of families who desperately needed the income from child labor to exist. ${ }^{108}$ Reuben Dagenhart, nominal plaintiff in a case attempting to invalid the Act, ${ }^{109}$ noted that while his father earned $\$ 15.00$ per week "he and his brother and sister brought in a total of $\$ 17.00$ per week" to sustain the family. ${ }^{110}$

\section{A. Roland Dagenhart and the Supreme Court}

"Test case" litigation, particularly in the federal courts, has long been the weapon of choice for powerful economic and politically conservative forces in the United States. Child labor is but one of many examples. ${ }^{11}$ Even before the passage of the Keating-Owen Act, employers, particularly Southern textile owners, prepared to challenge it. David Clark, son of a distinguished Southern jurist ${ }^{112}$ and publisher of the Southern Textile Bulletin, organized southern mill owners into the Southern Cotton Manufacturers, led by an active Executive Committee. $^{113}$ Clark was to become the key character in the child

107. Felt, supra n. 28, at 471.

108. See generally Zelizer, supra $\mathrm{n}$. 52, at 69-71.

109. See generally Hammer, 247 U.S. 251 (1918).

110. Felt, supra n. 28, at 471.

111. See Benjamin R. Twiss, Lawyers and the Constitution: How Laissez Faire Came to the Supreme Court 241-243 (Greenwood Press 1973) (Conservative Liberty League mounts court challenges to laws it had opposed in Congress); Carter v. Carter Coal Co., 298 U.S. 238, 340-342 (1936) (invalidating Bituminous Coal Act); A.L.A. Schechter Poultry Corp. v. U.S., 295 U.S. 495, 541-551 (1935) (invalidating National Industrial Recovery Act); Ex parte Young, 209 U.S. 123, 204 (1908) (creating fiction that suit against State Attorney General was suit against a private individual, negating Eleventh Amendment prohibition against suits against states in federal courts).

112. Wood, supra n. 48, at 42. Walter Clark, David Clark's father, was a progressive Chief Justice of the North Carolina Supreme Court and had been considered by President Woodrow Wilson for nomination to the United States Supreme Court. Id.

113. Wood, supra n. 48, at 42, 44-45; Hindman, supra n. 41 , at 66-67. In the spring of 1915, Clark organized the Executive Committee of Southern Cotton Manufacturers, hiring former North Carolina Governor W.W. Kitchin to fight passage of restrictions on child labor in Congress. Wood, supra n. 48, at 44-45, 48-49; Hindman, supra n. 41, at 66-67. In 1914, North Carolina Senator Lee Overman had blocked the Palmer-Owen child labor bill, which had passed the House by a vote of $237-45$, from coming to a vote in the Senate for over a year, but mill owners saw that 
labor litigation drama about to unfold. Upon founding the Southern Textile Bulletin in 1911, Clark used the trade journal to lead the industry in opposition to government intervention, unionism and other "evils." 114 His group funded court efforts opposing federal restrictions on child labor and vowed to take the fight to the Supreme Court. ${ }^{115}$

For this battle, Clark retained John G. Johnson, a brilliant Philadelphia corporate attorney and a long-time leader of the American bar, who, according to constitutional historian Edward S. Corwin had "shaped the American Bar Association into a 'sort of juristic sewing circle for mutual education in the gospel of Laissez Faire.",116 Although Johnson was in poor health, he maintained regular letter correspondence with Clark, advising him of case strategy. Among his most prescient comments to Clark was: "[i]f possible, a judicial district should be selected in which the judge is a man of known courage; this is no case to try before a weak character."117 After Johnson's death, he was replaced by attorney Junius Parker, ${ }^{118}$ a partner at O'Brien, Boardman, Parker and Fox of New York, one of the best known corporate law firms in the country. ${ }^{119}$ High powered local counsel were also retained, including Clement Manly of Winston-Salem and William P. Bynum of Greensboro, North Carolina. ${ }^{120}$

public sentiment was changing. Hindman, supra n. 41 , at 66 . "Realizing that they were unlikely to defeat the child labor bill again, their strategy was to delay its passage and 'load' the Congressional Record with arguments that could later be used in litigation." Hindman, supra n. 41, at 66-67; Wood, supra n. 48, at 48-51. Aside from the testimony offered by James Emery, general counsel of the National Association of Manufacturers, the Executive Committee was the only group opposed to child labor legislation to speak before Congress. Hindman, supra n. 41, at 66-67.

114. Wood, supra n. 48, at 42-43.

115. Hindman, supra n. 41, at 67. Many mill owners were pessimistic about success, but Clark aggressively pursed donations via the Southern Textile Bulletin to fund the legal battle. Id.

116. Wood, supra n. 48 , at 82 .

117. Id. at 88 .

118. Id. at 85. Parker was also general counsel for the American Tobacco Company, a leading litigator, and had participated in the landmark antitrust/monopoly suit U.S. v. Am. Tobacco Co., 221 U.S. 106 (1911). Id.

119. Id. The firm's senior partner, Morgan J. O'Brien, was one of a select group of lawyers who argued most of the important business litigation heard by the Supreme Court. Id.

120. Id. at 92. Manly and his firm, Manly, Hendron and Womble, were located in Winston-Salem. He was also an influential leader of the American Bar Association. Bynum was nationally known as one of the ablest southern counsels to appear before 
Clark and Attorney Parker met on several occasions to discuss the upcoming litigation. Rather than await criminal prosecution of a mill for violating the federal Keating-Own Act, which would take time and cede the choice of forum, they opted to affirmatively seek an injunction on behalf of a child employed in compliance with state law but threatened with dismissal because of the federal statute. ${ }^{121}$ Clark, the Southern Cotton Manufacturers, and their counsel chose James Edmund Boyd, of the Western District of North Carolina, as the most promising federal judge. ${ }^{122}$ Boyd had served in the Confederate Army, but later his conservative politics led him to the Republican Party, where he had been a member of the Republican National Committee. He was personally familiar with Clark's counsel. ${ }^{123}$ Clark next toured Judge Boyd's Western District of North Carolina in search of the "perfect combination of factors," and found four potential sets of plaintiffs. ${ }^{124}$ The Dagenhart family was ultimately selected, but had to be coaxed to join the lawsuit. ${ }^{125}$

Roland Dagenhart worked for the Fidelity Manufacturing Company, a small cotton mill, and had no intention of filing suit before he was approached by David Clark. ${ }^{126}$ Roland had two children who would be impacted by the federal child labor law. The older child, Reuben, was fifteen, and under North Carolina law could work up to eleven hours a day and sixty hours a week. ${ }^{127}$ Under the federal statute he would be reduced to eight hours a day. The younger Dagenhart, John, fourteen, was working up to eleven hours a day, but under the federal law would not be allowed to work at all. Little compensation was given to the Dagenharts for their participation in the case, although later Reuben would admit that he and his brothers received a few

the Supreme Court. Both firms had prominent lawyers who knew Federal District Judge Boyd both in and out of Court. Id.

121. Id. at 92-93. This strategy was modeled after the Arizona Anti-Alien case of two years prior where the threatened injury of denial of employment resulted in a successful injunction against the employer. See Truax v. Raich, 239 U.S. 33, 36 (1915).

122. Wood, supra n. 48, at 91-92. Boyd had been an Assistant Attorney General of the United States in 1897 under President McKinley, and in 1900 was named to the federal bench in the Western District of North Carolina. Id.

123. Id. at 92 .

124. Id.

125. Id. at 92-93; Hindman, supra $\mathrm{n} .41$, at 68.

126. Wood, supra $\mathrm{n}$. 48 , at 93.

127. Id. 
bottles of Coca-Cola and automobile rides for the use of their names in the lawsuit. ${ }^{128}$

On August 1, 1917, one month before the Keating-Owen Act was to go into effect, officials at the Fidelity Manufacturing Company posted a copy of the statute in their plant. A week later, on August 9, the complaint was filed in Federal Court with Fidelity and William C. Hammer, the U.S. Attorney for the Western District of North Carolina, named as defendants. ${ }^{129}$ Plaintiff alleged that the Dagenhart boys were employed in compliance with the child labor laws of North Carolina, and that federal enforcement of the Keating-Owen Act would deprive the elder Dagenhart of his vested rights to the services and wages of his minor sons. ${ }^{130}$ It was further alleged that his family was poor, and that he (Roland) needed the compensation from his children's labor. ${ }^{131}$ The suit argued the statute was beyond Congress' Commerce Clause power because it regulated conditions of manufacturing and contravened the Tenth Amendment. ${ }^{132}$ In addition, enforcement would deprive plaintiffs of liberty and property without due process of law under the Fifth Amendment. All these were familiar themes in the constitutional jurisprudence of the Lochner era. ${ }^{133}$

The U.S. Attorney in North Carolina immediately contacted the Department of Justice (DOJ) in D.C. to determine if it wanted to accept the challenge on the merits or wait for a better case. ${ }^{134}$ Reform groups urged the DOJ to hire special government counsel for this important litigation, and Thomas Parkinson, the director of the Legislative Drafting Bureau at Columbia Law School, who had assisted in drafting the bill in Congress, was immediately retained. ${ }^{135}$ Roscoe Pound, Dean of the Harvard Law School, was also retained, working pro bono. $^{136}$

Immediately after the filing of the complaint on August 9, Judge Boyd ordered Fidelity Manufacturing and the United States Attorney to

128. Hindman, supra $\mathrm{n} .41$, at 68 .

129. Wood, supra n. 48 , at $96-97$.

130. Id. at 97.

131. Id.

132. Id.

133. See generally Chemerinsky, supra $\mathrm{n} .87$, at 614-616.

134. Wood, supra n. 48, at 99.

135. Id. at 100 .

136. Id. at $100-101$. 
show cause within twenty days as to why he should not issue an injunction. On August 27, Fidelity filed its Answer to the plaintiff's Complaint and was never heard from again at the trial and appellate levels. ${ }^{137}$ Its response to the Dagenhart's allegations was friendly and cooperative, admitting all the complaint's factual allegations and the legal issue at hand. ${ }^{138}$ U.S. Attorney Hammer responded in succinct fashion on August 29 with a one sentence Motion to Dismiss, asserting the law's constitutionality. ${ }^{139}$ That same day, Judge Boyd denied the Motion to Dismiss and both sides immediately agreed to narrow the argument to the issue of the constitutionality of the statute. ${ }^{140}$

At the hearing before Judge Boyd on August 30, the Southern Cotton Manufacturers' attorneys-acting in the name of the Dagenharts-argued that manufacturing was not part of interstate commerce and congressional authority did not extend to productive activities. ${ }^{141}$ Attorney Bynum supplemented this by discussing the nature of child-made goods. ${ }^{142}$ While Congress had the power to close the channels of interstate commerce to articles injurious to public health, morals or safety, it possessed no power over articles that were not themselves inherently dangerous. ${ }^{143}$ Parkinson led the government defense before Judge Boyd, but conceded that the Act was a departure from prior legislation. ${ }^{144}$ Parkinson's concession was highly contentious within the defense team, as Dean Pound and others in the DOJ believed that Parkinson should have argued that the Act fit easily with prior national police power precedent in the Supreme Court. ${ }^{145}$

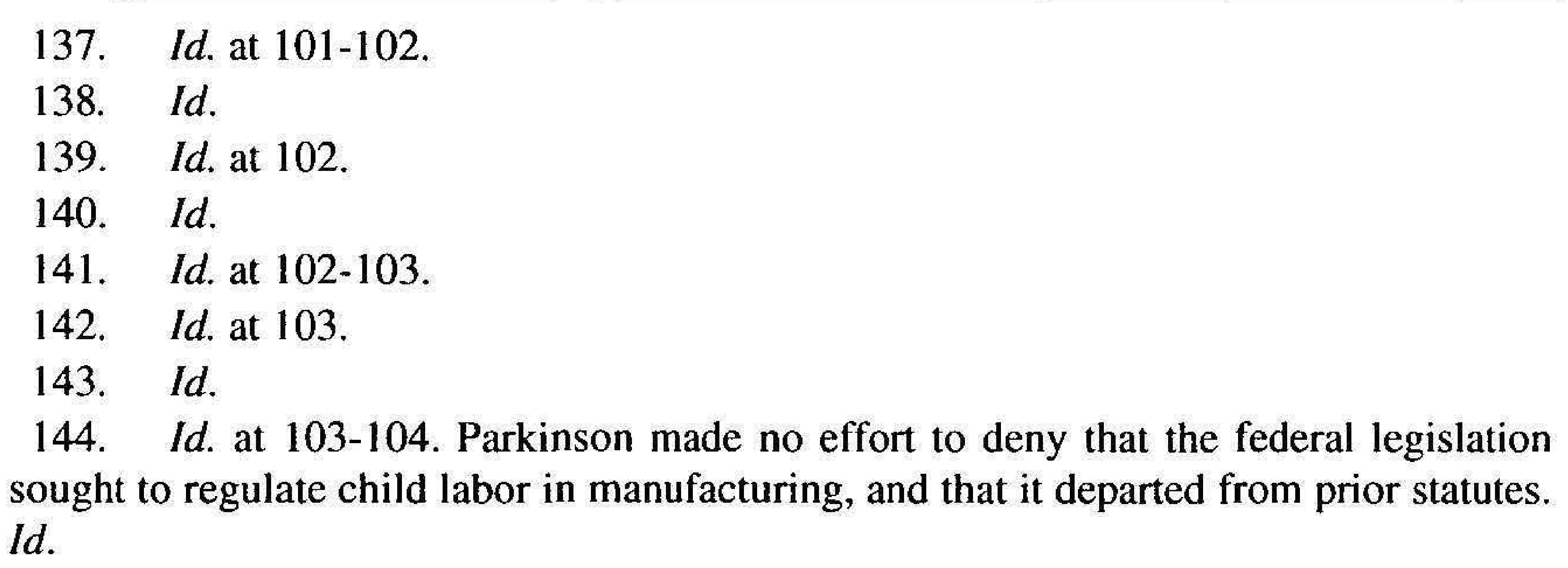

145. Id. at 107-108. In a letter dated September 3, 1917, Pound wrote to U.S. Attorney Gregory Pound:

Through an unhappy misunderstanding, the government did not present a consistent case. The district attorney and I understood that we were to argue that in principle there was nothing about the law which the Supreme Court had not already sanctioned. But Mr. Parkinson did not understand it as we did and in his argument conceded the position for which the plaintiffs had 
Judge Boyd's decision to enjoin the Act came on August 31, but he never filed a written opinion. ${ }^{146}$ In an oral statement to both parties endorsing plaintiff's arguments, he found the Act unconstitutional because it was not a regulation of interstate commerce and contravened the powers of the states under the Tenth Amendment. ${ }^{147}$ Judge Boyd specifically noted Attorney Parkinson's concession that the KeatingOwen Act was unprecedented. ${ }^{148}$ Congress could regulate trade among the states, but not the conditions of labor producing the merchandise that was traded. ${ }^{149} \mathrm{He}$ also spoke at length about the right of the progenitor to control the behavior of his progeny, and warned about social legislation that placed children in the power of the law or police. ${ }^{150}$ Judge Boyd then issued a terse injunction, enjoining Fidelity from refusing to employ the Dagenhart boys and the United States Attorney from attempting to enforce the provisions of the child labor bill anywhere in the Western District of North Carolina. ${ }^{151}$

The journey from Judge Boyd's decision on August 31 to the United States Supreme Court was brief. On September 1, 1917, U.S. Attorney Hammer filed both an Assignment of Errors ${ }^{152}$ and a Motion for Appeal to the Supreme Court. ${ }^{153}$ On September 18, Judge Boyd issued a citation to both parties to appear before the High Court on October 18,1918 to present oral argument. ${ }^{154}$

By the time the case was argued before the Supreme Court, the nominal parties, Fidelity Manufacturing and the Dagenharts, were absent and only the Southern Cotton Manufacturers and the

\footnotetext{
been contending ....and asserted that the case was to be a landmark in constitutional law. Id.

146. Id. at 105. In his oral opinion, Judge Boyd did not cite to precedent or analyze previous cases. He issued an injunction against following the Keating-Owen Act in the Western District of North Carolina. Judge Boyd simplified the issue: "Can Congress do by indirection that which it undoubtedly cannot do directly?" Id. at 105106.

147. Wood, supra n. 48 , at 105-106.

148. Id. at 105 .

149. Id. at 106 .

150. Id.

151. Id at 107.

152. Id. at 108.

153. Id.

154. Id.
} 
Department of Justice remained to prepare and argue the case. The briefs had presented well-rehearsed legal arguments and well known precedent. The government stressed Brandeis Brief facts, focusing on the health detriments of premature child work. ${ }^{155}$ It described, for example, the alarming percentage of tuberculosis deaths in cotton mills:

...Operatives, thus, of the most youthful age group were four times, those of the post puberty were twice, and those of the young adult group - 20 to 24 - were about two and a half times as liable to die from tuberculosis as were, respectively, the girls of like age that did not work in cotton mills. $^{156}$

Evidence of loss of education, increases in crime and other ills resulting from youth employment were advanced to support Congress' legitimate legislative purpose of protecting public health. ${ }^{157}$ The government's brief also focused on the inability of states to regulate child labor on their own because of the opportunity of employers seeking cheap wages to flee to states with little or no regulation of child labor. ${ }^{158}$ These employer actions utilized the channels of commerce for unfair competition. ${ }^{159}$

In addition, the government, contrary to Parkinson's concession in the District Court, argued that recent constitutional precedent clearly supported Congress' power to enact the Keating-Owen Act. Champion v. Ames, in 1903, had upheld a similar federal statute prohibiting interstate shipment of lottery tickets, rejecting both Commerce Clause and Tenth Amendment challenges. ${ }^{160}$ Other federal statutes prohibiting transportation of women across state lines for immoral

155. See id. at 145.

156. Br. for Appellant at 12-13, Hammer, 247 U.S. 251 (1918) in Landmark Briefs of the United States Supreme Court: Constitutional Law Vol. 18 (Philip B. Kurland \& Gerhard Kasper, eds., U. Pub. of Am. 1975) [hereinafter Br. for Appellants]. Even in relatively nonhazardous occupations, "the [tuberculosis] rate for the child is more than double for the older worker." Id. at 13 (citing Sen. Rpt. 64-358 at 14 (1916)).

157. Id.

158. Id. at 23-35.

159. Id. at 30-35.

160. 188 U.S. 321, 354-357 (1903) (holding "lottery tickets are subjects of commerce and regulation of the carriage of such tickets...is a regulation of commerce"). 
purposes $^{161}$ and regulating shipping of adulterated food and drugs ${ }^{162}$ were also arguably supportive of Congress' power. State statutes limiting child labor had been upheld against Fourteenth Amendment challenges because of overriding health and safety concerns and the Fifth Amendment attacks should fare no better. ${ }^{163}$

The Southern Cotton Manufacturers' brief ${ }^{164}$-nominally filed on behalf of the Dagenharts-concentrated on two constitutional themes to which the Court of that period was extraordinarily receptive: fear that overweening federal legislative power would eclipse the rightful role of state and local governments, and protection of the rights of parents over the upbringing and labor of their children. In the background lurked the issue of race. ${ }^{165}$ If Congress could constitutionally control child labor, what could prevent it from dismantling state-created racial segregation, ${ }^{166}$ repeatedly upheld by the Supreme Court? ${ }^{167}$ Each of these rhetorical gambits played important roles in the ultimate decision in Hammer. They pushed the

161. Hoke v. U.S., 227 U.S. 308, 320 (1913).

162. Hipolite Egg Co. v. U.S., 220 U.S. 45, 51 (1911).

163. Br. for Appellants at 40-48.

164. See generally Br. for Appellees at 1, 1-62, Hammer, 247 U.S. 251 (1918) in Landmark Briefs of the United States Supreme Court: Constitutional Law Vol. 18 (Philip B. Kurland \& Gerhard Kasper, eds., U. Pub. of Am. 1975) [hereinafter Br. for Appellees].

165. Id. at 13-14, 40-42.

166. Id. at 40 . The brief noted that if national interest and consumer sensitivity became the basis for power for Congress to act, it could then act in a variety of issues thought to be "national evils" by many people.

It is abhorrent to many people that negroes should not have the same industrial opportunities that whites enjoy; therefore Congress may provide that no factory which refuses to employ negroes, side by side with whites, may ship its goods in interstate commerce...It is hard to distinguish between the fanciful idea of supersensitive consumers ....and the cases in which Congress should conclude that it was abhorrent to the moral sense of the community to have people engaging in interstate commerce from a State which did not permit woman suffrage ... or did not permit the sale of liquor...

Id.

167. See e.g. Cumming v. Bd. of Educ., 175 U.S. 528, 545 (1899) (local authorities have discretion in allocating funds between black and white schools); Plessy $v$. Ferguson, 163 U.S. 537, 550-552 (1896) (upholding constitutionality of racially segregated facilities); The Civil Rights Cases, 109 U.S. 3, 17-19 (1883) (striking down federal civil rights statutes): U.S. v. Harris, 106 U.S. 629, 643-644 (1882) (Congress lacked power to make the lynching of black prisoners held by state deputy sheriff a federal crime). 
majority of the Court to distinguish prior precedent, which seemed to control the case, and launch a series of confrontations with Congress that only ended with the Court's 1937 "switch in time which saved nine." 168

The Southern Cotton Manufacturers' brief concentrated on the structural constitutional division of powers between national and state governments. It noted, ostensibly paradoxically, that almost all states had, in their own fashion, dealt effectively with the issue of child labor, a necessary evil. ${ }^{169}$ National regulation on the topic could not take account of the "infinite variations of climatic, social and other conditions" in the United States. ${ }^{170}$ Included in these "infinite variations" were the differing ages children mature in different states; ${ }^{171}$ how "negros" reached physical maturity at an earlier age than whites $;{ }^{172}$ and how different parts of the country have different cultural attitudes towards factory work for women and children. The KeatingOwen Act was thus a federal attempt to average the climate, wealth, and racial customs of varying states. ${ }^{173}$

The Southern Cotton Manufacturers' brief also argued that if Congress could proscribe child labor conditions, what constitutional barrier was there to regulation of minimal wages for adults, or federal legislation affording the same job opportunities for "negros" and whites? ${ }^{174}$ Validation of congressional power over working conditions of children would lead to the "complete elimination of the States as political entities", ${ }^{175}$ only the High Court could restrain Congressional subversion of our Constitutional structure. ${ }^{176}$

168. Chemerinsky, supra $\mathrm{n} .87$, at 256.

169. Br. for Appellees, supra n. 164, at 10. "Not only have states passed statutes addressing child labor, but in many of them there have been progressive steps taken to protect the health, vigor, and safety of the coming generation". Id.

170. Id. at 9 .

171. Id. The brief discussed, for example, how Louisiana statutes allowed children to marry at age twelve but many other states forbade marriage until later ages. Id.

172. Id.

173. Id. at 13.

174. Id. at 40.

175. Id. at 14.

176. See id. at 61-62.

[B] ut for the Federal Government to attempt to create a privileged class of citizens of the States who may engage in interstate commerce, or whose products may be embarked in interstate commerce, involving, as this does, the creation of another class, of whose conduct Congress does not approve, 
A second major theme of the Southern Cotton Manufacturers' brief was protection of parental decision- making over children, enshrined in the Due Process Clauses of the Constitution. ${ }^{177}$ This was another important constitutional theme of the Court in the 1920s, explaining a number of key decisions. ${ }^{178}$ This argument was paired with the specter of poverty-stricken families unable to use their childrens' earnings even in the most dire economic conditions. The brief noted that Roland Dagenhart was "a man of small means with a large family" for whom "the compensation arising from the service of each of said minor sons was essential for the comfort and maintenance of the family, including said minors." noted the disagreement and conflicting arguments the Government had presented at the District Court. ${ }^{180}$

At the oral argument in Hammer the courtroom was packed with legal and business notables, already in Washington to participate in the war effort. All recognized the importance of the case. ${ }^{181}$ Solicitor General John W. Davis began the oral argument late in the day on

which is denied those privileges, is beyond the limits of the fundamental principles of liberty and justice, and not in accordance with the nature of the Federal State ... If our institutions mean anything, and our Constitution is more than a scrap of paper, the statement of that suggestion [Congressional Id. subversion of our Constitutional structure] carries its own refutation.

177. Id.

178. I am indebted to Professor Barbara Bennet Woodhouse for this insight. See generally Woodhouse, supra $\mathrm{n}$. 53, at 1113-1117, 1068-1085. "By constitutionalizing a patriarchal notion of parental rights, Meyer and Pierce interrupted the trend of family law moving towards children's rights and revitalized the notion of rights of possession." Id. at 1113 .

179. Br. for Appellees, supra n. 164, at 3.

180. Id. at 23-24.

"In the court below, eminent counsel for the defendant-appellant were in disagreement as to the theory upon which this statute was to be defended.... One counsel seemed to concede that before commerce in a given article could be prohibited ...there must be an evil involved in, or arising out of, the commerce... The other counsel ...disagreed with this view, because he thought it valid and proper for Congress to regulate the prior conduct of the persons who desire to engage in interstate commerce...He represented the group who frankly believe that in this power to regulate commerce there resides in Congress a method of regulating the entire conduct of the modern man."

Id.

181. Wood, supra n. 48 , at 151. 
April 15, 1918, continuing his presentation early the following day. ${ }^{182}$ Davis immediately drew heated judicial responses to his contention that "underlying this statute is the conviction that child labor is always and everywhere inherently an evil thing and all statutes are a reflection of prevailing opinion in the public mind."183 Davis, who had in the past been called the "fair haired boy who could do no wrong in front of the Court," was forced to repeatedly defend his assertion that legal doctrine made permissible what dominant opinion justifiably demanded. ${ }^{184}$

The Cotton Manufacturers' arguments, presented by attorneys Morgan J. O'Brien and William Hendren, failed to generate the same interest from the Justices. ${ }^{185}$ However, Chief Justice White repeatedly inquired whether Congress had, in passing the Thirteenth Amendment, assumed responsibility for the maintenance of a "virile citizenship," i.e., a healthy and informed citizenry, thus leading to the purpose and need for the Keating-Owen Act. ${ }^{186}$ Solicitor General Davis saw this as evidence of a favorable outcome for the Government. ${ }^{187}$ In this instance, Davis misinterpreted the Chief Justice's interest, and the confidence that he and the child labor reformers felt after oral argument was shortly to be proven wrong.

The Supreme Court's five to four decision, on June 3, 1918, dealt a fatal blow to congressional restrictions on child labor. The majority opinion distinguished prior legitimation of federal statutes on the basis that "the use of interstate transportation was necessary to the accomplishment of harmful results [in those cases] ... [t] this element is wanting in the present case." 188 The Keating-Owen Act breached Congress" constitutional boundary in two ways: "[i]t not only transcends the authority delegated to Congress over commerce but also exerts a power as to a purely local matter to which the federal authority does not extend." 189 To allow this regulation would open the door to a

182. Id.

183. Id. at 152. Davis believed that in order for the Government to win, the Justices needed education in the facts and statistics of child labor, rather than in the relevant legal principles, which many on the bench had themselves written. Id. at 145 .

184. Id. at 152 .

185. Id.

186. Id.

187. Id.

188. Hammer, 247 U.S. at 271.

189. Id. at 276. Approval of the Keating-Owen Act might bring federal control 
host of unconstitutional usurpations, including the fixing of wages and control over children. ${ }^{190}$

The majority opinion tracked Judge Boyd's and the Southern Cotton Manufacturers' arguments. While there could be "limitations upon the right to employ children in mines and factories in the interest of their own and the public welfare" only the states could exercise that power. ${ }^{191}$ Here the majority, in good Asian martial arts manner, used the Progressives' legislative success in passing state restrictions on child labor as a weapon against the exercise of power by Congress. In concluding, the majority sounded an apocalyptical note. "[I]f Congress can thus regulate matters entrusted to local authority ... all freedom of commerce will be at an end, and the power of the states over local matters may be eliminated, and our system of government be practically destroyed." 192

Justice Oliver Wendell Holmes penned an eloquent dissent. States were free to act on child labor, but the Keating-Owen Act did not preempt any state's efforts on this topic. ${ }^{193}$ But states' regulation of child labor was ineffective precisely because of the disability placed upon them by competition from other states and their parochial interests. Congress' commerce power was unqualified under the Constitution and the legislature, ${ }^{194}$ not the Court, was best able to determine what type of regulation of child labor was in the nation's best interest. ${ }^{195}$

[I]f there is any matter upon which civilized countries have agreed ...it is the evil of premature and excessive child

over matters that were uniquely subject, under the Tenth Amendment, to the state police power and diminish the state's ability to exercise a unique relationship with children. Id.

190. Id.

191. Id. at 275.

192. Id. at 276.

193. Id. at 281 (Holmes, J., dissenting). States were undoubtedly within their power to "regulate their internal affairs and their domestic commerce as they like." Id.

194. Id. at 280-281 (Holmes, J., dissenting). Although states could regulate their own domestic commerce, "when they seek to send their products across the state line they are no longer within their rights." Id.

195. Id. at 277-278 (Holmes, J., dissenting). Holmes' dissent also focused on the many instances where the Court had upheld regulations passed under the Commerce Clause for reasons indistinguishable from the majority's rationale. "Congress's power to regulate commerce was unqualified under the Constitution. ..." Id. 
labor. I should have thought that if we were to introduce our own moral conceptions wherein in my opinion they do not belong, this is preeminently a case for upholding the exercise of all of its powers by the United States. ${ }^{196}$

Later, when asked about his "victory" in the Supreme Court, Rueben Dagenhart, now twenty, retorted:

We got some automobile rides. They bought both of us a Coca-Cola. That's what we got out of it' he told an interviewer. Look at me! A hundred and five pounds, a grown man and no education. I may be mistaken, but I think the years I've put in the cotton mills have stunted my growth. They kept me from getting any schooling. I had to stop school after the third grade and now I need the education I didn't get. It would have been a good thing in this state if that law they passed had been kept. ${ }^{197}$

1. Impact of the Decision

Before being explicitly overruled in $1941,{ }^{198}$ Hammer $v$. Dagenhart, exerted an important influence on state and federal decisions, including those by the Supreme Court. Hammer was relied upon by federal circuit and district courts to invalidate a number of important federal statutes. These courts used Hammer to hold that Congress could not regulate various subjects because they were reserved to the states and were not "commerce" for the purposes of the Commerce Clause. In addition to lower courts, multiple Supreme Court cases cited the decision between 1918 and 1937. ${ }^{199}$ In all, Hammer was cited by 151 state and federal cases between 1918 and $1937 .^{200}$

196. Id. at 280 .

197. Hindman, supra n. 41, at 68 .

198. See U.S. v. Darby, 312 U.S. 100, 116 (1941).

199. See generally Carter v. Carter Coal Co., 298 U.S. 238, 295 (1936); U.S. v. Chi., M., St. P. \& P.R. Co., 282 U.S. 311, 324 (1931); Nigro v. U.S., 276 U.S. 332, 339 (1928); U.S. v. Daugherty, 269 U.S. 360, 362 (1926); Brooks v. U.S., 267 U.S. 432, 438 (1925); United Leather Workers' Intl Union v. Herkert \& Meisel Trunk Co., 265 U.S. 457, 465 (1924); United Mine Workers of Am. v. Coronado Coal Co., 259 U.S. 344,408 (1922).

200. Results obtained through Westlaw by retrieving the citation for Hammer $v$. Dagenhart and accessing the "citing references" tool. The citing references were limited by Westlaw's "limit" tool to court decisions of all jurisdictions issued between 
In 1934, for example, the District Court of Maryland held the National Industrial Recovery Act unenforceable. ${ }^{201}$ The defendant argued that the Act was inapplicable because he did not engage in interstate commerce. ${ }^{202}$ The court cited Hammer as the "only necessary obstacle" to a broader conception of using the commerce power to reach internal state activities. ${ }^{203}$ The same court also found another important federal statute, the Public Utility Holding Act, unconstitutional. ${ }^{204}$

In other illustrative examples, the Eastern and Western District Courts of Missouri relied upon Hammer to find that Congress could not regulate manufacturing activities. ${ }^{205}$ In United States v. National Garment, ${ }^{206}$ the court supported its conclusion that the means of production were constitutionally reserved for state regulation by quoting extensively from Hammer. ${ }^{207}$ A similar approach was taken in Hume-Sinclair Coal Mining Co. v. Nee involving the Bituminous Coal Conservation Act. ${ }^{208}$

1918-1937.

201. U.S. v. Mills, 7 F. Supp. 547,559 (D. Md. 1934), dismissed, 77 F.2d 1019 (4th Cir. 1985) (by agreement of counsel).

202. Id. at 559.

203. Id. at 549. The court stated that the government's argument to expand the Commerce Clause would require overruling Hammer. Id. Also in 1934, the Southern District of Illinois held that Congress could not regulate "filled milk" because it could not override states' judgments. U.S. v. Carolene Prod. Co., 7 F. Supp. 500, 506 (S.D. III. 1934). The court quoted Hammer at length because it showed the Supreme Court "endeavoring to protect the states." Id. at 504. Carolene Products involved "the precise principle which were (sic) discussed and applied by the Supreme Court" in Hammer. Id. at 507.

204. In re Am. States, 12 F. Supp. 667, 699 (Md. 1935). The court described Hammer as deciding "constitutional provisions, [that] whether operating by way of grant or limitation, are not to be evaded by legislation which, although not in terms trespassing upon the letter and spirit, yet in substance or effect destroys, the grant or limitation." In reaching its decision, the court quoted extensively from Hammer and Bailey v. Drexel.

205. U.S. v. Natl. Garment Co., 10 F. Supp. 104, 106 (E.D. Mo. 1935); HumeSinclair Coal Mining Co. v. Nee, 12 F. Supp. 801, 804 (W.D. Mo. 1935).

206. Natl. Garment, 10 F. Supp. at 108.

207. Id.

208. Hume-Sinclair, 12 F. Supp. at 804-805 (also discussing the Child Labor Tax cases). See also St. Louis-S.F. Ry. Co. v. Conly, 241 S.W. 365, 367 (Ark. 1922) (holding the federal government could not "in any manner trench upon or dislodge the police power of the states over their own local and internal affairs which are reserved to them under the Tenth Amendment to the Constitution"). 


\section{B. Bailey v. Drexel Furniture}

After their defeat in Hammer, the NCLC and the Children's Bureau sought to use Congress' power to tax, rather than the delegitimized commerce power, to restrict youth employment. ${ }^{209}$ Child labor reformers in Congress turned to a different line of promising Supreme Court precedent, particularly McCray v. U.S. in 1904. ${ }^{210}$ In McCray Justice White held that the Court was barred from inquiring into the motives of Congress in tax matters. ${ }^{211}$ White, of course, had been in the majority in the five to four Hammer decision and thus might be swayed to uphold a child labor tax. No congressional hearings were held before passage of the 1918 Tax Revenue Act, ${ }^{212}$ which included a $10 \%$ excise tax on the net profits of businesses using prohibited child labor, defined in the same terms as those used in the invalidated Keating-Owen Act. ${ }^{213}$ The Tax Revenue Act also empowered the Commissioner of the Internal Revenue Service

209. The months after the Dagenhart decision were tumultuous for child labor reformers. Some wanted to await a shift in the Court's view of federalism before attempting federal legislation again. Others contemplated ways to circumscribe judicial review and diminish the Court's power or some advocated for a constitutional amendment. Senator Kenyon considered a bill that used the congressional powers over mail to regulate child labor. See Wood, supra n. 48, at 188-193.

210. McCray, 195 U.S. 27.

211. In McCray the Court upheld a federal tax levied on margarine products, a victory for producers of competing spreads and Congress' power under Article I, $\S 8$, Clause 1. Justice White noted:

Applying this rule to the acts assailed, it is self-evident that on their face they levy an excise tax. That being their necessary scope and operation, it follows that the acts are within the grant of power. The argument to the contrary rests on the proposition that, although the tax be within the power, as enforcing it will destroy or restrict the manufacture of artificially colored oleomargarine, therefore the power to levy the tax did not obtain. This, however, is but to say that the question of power depends, not on the authority conferred by the Constitution, but upon what may be the consequence arising from the exercise of lawful authority.

Id. at 59 .

212. Wood, supra n. 48, at 196.

213. Keating-Owen Act of 1916, Pub. L. No. 249, 39 Stat. 675 (1916), invalidated, Hammer v. Dagenhart, 247 U.S. 251 (1918). The language of the Keating-Owen Act was mirrored in the 1918 Tax Revenue Act, further fueling opposition arguments that the Tax Act was not intended for tax revenue purposes, but to regulate manufacturing prohibited by the Hammer decision. Compare Keating-Owen Act of 1916, Pub. L. No. 249, 39 Stat. 675 (1916), invalidated, Hammer v. Dagenhart, 247 U.S. 251 (1918) with the 1918 Tax Revenue Act, Ch. 18, Title XII, 40 Stat. 1057 (1919), invalidated, Bailey v. Drexel, 259 U.S. 20 (1922). 
to inspect facilities to ensure employer compliance with the terms of the Act. ${ }^{214}$ Reformers believed that the High Court could not overturn the Tax Revenue Act without reversing McCray.

Even before the tax was enacted, Clark mobilized the Southern Cotton Manufacturers to challenge it. The strategy, as before, was to use a father and son as plaintiffs in a suit, again before District Judge Boyd. After another search in the Western District of North Carolina, Clark solicited Eugene T. Johnston, an employee at the Atherton Mills, ${ }^{215}$ to be the plaintiff in the new litigation. ${ }^{216}$ As his son, John W. Johnston, then fifteen, would have had his hours reduced, Johnston agreed. $^{217}$ On May 2, 1919, Johnston v. Atherton Mills was heard before Judge Boyd, argued by Clark's corporate lawyers fresh from their success in Hammer v. Dagenhart. ${ }^{218}$ The issue was decided almost before the case began. Immediately after the plaintiffs' attorney commenced his opening statement, ${ }^{219}$ Judge Boyd announced that the statute was unconstitutional, and that no further argument was necessary. Congress was once more infringing upon the rights of the states. $^{220}$ Unlike Dagenhart, however, the injunction, inexplicably, was solely in favor of the Johnstons. 221

Given the narrowness of the order, the U.S. District Attorney chose not to pursue the case further. Clark and the Southern Cotton Manufacturers had been counting on the Government to appeal the case, and when it failed to do so, Clark brought Atherton Mills back before Judge Boyd to file an appeal to the Supreme Court. Clark's attorneys now argued that Atherton had the right to fire John Johnston because of the 1918 Tax Revenue Act. ${ }^{222}$ When the Supreme Court

214. Revenue Act of 1918, Pub. L. No. 276, 1200, 40 Stat. 1057, 1203 (1919).

215. Atherton Mills was one of the many mills owned by D.A. Tomkins, another opponent of child reform efforts both in North Carolina and nationally. Tompkins was well known for speeches maintaining that over-indulgence and slothfulness contributed as much harm to children as child labor. He also campaigned aggressively in North Carolina to allow lower ages for working children operating in an apprenticeship capacity. See Hindman, supra n. 41, at 55, and Davidson, supra n. 92, at 157.

216. See Hindman, supra n. 41, at 70.

217. Id.

218. Wood, supra n. 48 , at 221.

219. Id. at 229.

220. Id. at 228 (citing Transcript of Record at 12, Atherton v. Johnston (April 23, 1919)).

221. Id. at 221.

222. See id. at 230 . 
agreed to hear the appeal, Atherton invited the Department of Justice to defend the constitutionality of the child labor tax, which it did. ${ }^{223}$

Atherton Mills $v$. Johnston was argued at the Supreme Court on December 10, 1919. ${ }^{224}$ There is no record of the oral argument. By this time, however, John Johnston had turned sixteen and the controversy seemed moot. By 1920 , with still no ruling, both sides were becoming nervous. Clark had hoped for an early decision because by April 1920 mills were required to file tax returns admitting or denying liability for the $10 \%$ child labor tax. ${ }^{225}$ Still there was silence from the High Court.

The reason for the delay in Johnston has never been determined. Some have speculated that Chief Justice White was the reason for the lack of a decision. For White the issues of the case straddled a doctrinal fence: the government's heavy reliance in its brief upon his opinion in $\mathrm{McCray}$ meant either finding differences between that case and Johnston in order to overturn the 1918 Tax Revenue Act, or reversing his own decision of two decades earlier. ${ }^{226}$ White, moreover, was in rapidly failing health. ${ }^{227}$

Finally, as the parties studied the poor financial results from two years of enforcement of the Tax Revenue Act, ${ }^{228}$ in the spring of 1921, the High Court ordered re-argument for the following October. Only weeks into newly-elected President Warren Harding's term, Chief Justice White died on May 19, 1921. His replacement was former President William Howard Taft. From his past writings and speeches, ${ }^{229}$ Clark and the Southern Cotton Manufacturers were

223. Id. at 231.

224. Atherton Mills v. Johnson, 259 U.S. 13 (1922).

225. See Hindman, supra n. 41 , at 71 .

226. Wood, supra n. 48, at 242.

227. Id. at 241.

228. The Bureau of Internal Revenue had allocated $\$ 90,000$ for enforcing the Act in its first year of operation. In that first year, however, it only collected $\$ 2,000$ in fines. Wood, supra n. 48, at 253. By the time the Supreme Court ruled the Act unconstitutional three years later, the tax had cost over $\$ 300,000$ to administer, while raising approximately $\$ 41,000$ in revenue. The National Committee of Child Labor noted these disappointing results, and was especially worried about the problems the discrepancy would cause. Hindman, supra $\mathrm{n} .41$, at 72.

229. See Br. for Appellees, supra n. 164 at 57. The Southern Cotton Manufacturers' lawyers quoted President Wilson's compilation of "Lectures on Popular Government" published in 1913:

If the power to regulate commerce between the states can be stretched to 
confident Taft was a reliable fifth vote in their favor. In the fall of 1921 the Johnston case was argued for a second time, but now was joined by two other cases manufactured by the mill owners and decided by Judge Boyd, Vivian Mills v. J.W. Bailey ${ }^{230}$ and Bailey v. Drexel. ${ }^{231}$

These new cases had interesting litigation histories. Clark and his counsel had been deeply concerned about the jurisdictional deficiencies of their Johnston test case, so they had again scoured the Western District for a cotton mill that had resisted the $10 \%$ tax penalty. ${ }^{232}$ Finding none, Clark turned to other manufacturers for a test case. ${ }^{233}$ He utilized a list obtained from the Internal Revenue in Raleigh, North Carolina, listing manufacturers recently assessed the $10 \%$ penalty under the Tax Act. ${ }^{234}$ Meanwhile his lawyers, Manly and Hendren, wrote President Harding's new Solicitor General, James M. Beck, suggesting the Johnston case be delayed due to the "probability of a case being docketed during the early months of the term which will be free from any question of jurisdiction." 235 Beck, eager to decide the constitutional issue, agreed. ${ }^{236}$

In October of 1921 Clark's lawyers assisted the Drexel Furniture Company in submitting a petition for a tax refund and initiating another federal suit before Judge Boyd. ${ }^{237}$ To expedite the case, U.S. Solicitor General Beck instructed the new District Attorney for Western North Carolina, F.A. Linney, to file a demurrer, asserting the child labor tax was constitutional. On December 10,1921, the case was heard in North Carolina's Western District Court. Unsurprisingly, Judge Boyd once more immediately ruled against the government.

Breaking with his past practice of orally rendering opinions from the bench, this time Boyd drafted an opinion. He ignored the Supreme

include the regulation of labor in mills and factories, it can be made to embrace every particular of the industrial organization and action of the country.... May Congress also regulate the conditions under which Id. merchandise is produced? Clearly not.

230. See Hindman, supra n. 41, at 72.

231. Id.

232. Wood, supra n. 48 , at 260.

233. Id.

234. Id.

235. Id. at 261 .

236. Id.

237. Id. at 264. 
Court precedent in $\mathrm{McCray},{ }^{238}$ holding that "the necessary result of the statute must be taken into consideration, even if that result is not in so many words either enacted or distinctly provided for. In whatever language a statute may be framed, its purpose must be determined by its natural and reasonable effect." 239 Relying on his Summer 1921 decision in George v. Bailey ${ }^{240}$ and ignoring Supreme Court precedent that held a federal suit could not be entertained to restrain a tax, Judge Boyd re-asserted that states were the only entities able to address child labor:

By comparing the federal and state statutes it will be readily seen that the latter affords as much protection to the health and physical condition of children as the former...[i]nstead of undertaking as the federal act, to make the income of an establishment using child labor illegally, the subject of taxation, it denounces as a criminal offense the violation of its provisions ...

[F]or this reason the state statute is undoubtedly more capable of prompt execution than the act of Congress, and the expenses incident to it when compared to that of the federal plan, must necessarily be a great deal less. ${ }^{241}$

In this Bailey v. Drexel decision all the interested parties-the Government as well as Clark and his Textile Manufacturers-now had a viable case to ensure the High Court would address the constitutionality of the 1918 Tax Revenue Act.

238. See supra $\mathrm{nn} .210-211$ and accompanying text.

239. Drexel Furniture Co. v. Bailey, 276 F. 452, 454 (W.D. N.C. 1921).

240. George v. Bailey, 274 F. 639, 644 (W.D. N.C. 1921). This case is also known as the Vivian Cotton Mill or Vivian Spinning Mill case. Its convoluted facts did not make it an attractive test scenario for Clark's lawyers. In 1919, while operating under the name of Vivian Cotton Mills, the Internal Revenue of North Carolina assessed the owner, Mr. George a $\$ 2,098$ fine for illegally employing children. Attempting to rid himself of this liability, the ownership of the company was transferred to a new entity, the Vivian Spinning Mills. The North Carolina Tax Collector, Bailey, demanded the money and threatened to seize the property and dispose of it by sale. The Mill filed a lawsuit, requesting that Bailey be enjoined from acting because the Child Labor Tax was unconstitutional under the Fifth and Tenth Amendments. The Supreme Court had previously held in McCray, 195 U.S. at 54 (1904), that no federal suits could be entertained to restrain a tax; rather reimbursement must be sought. Judge Boyd waived this "technicality" to issue an injunction against Bailey. George, 247 F. at 642; see Wood, supra n. 48, at 265-266.

241. George, 274 F. at 643 . 
At the March 8, 1922, oral argument in the Supreme Court in Bailey v. Drexel, Solicitor General Beck was subjected to repeated hard questioning, forced to defend the discrepancy between the cost of administering the tax versus its small income. ${ }^{242}$ Chief Justice Taft was particularly hostile, demanding that Beck explain how the Court should determine congressional intent for the statute and the limits of federal regulatory authority over production in the states. ${ }^{243}$ Most observers felt the argument went badly for the Government and Beck himself acknowledged this in a letter to Chief Justice Taft after the decision. $^{244}$ Child labor reformers were already suspicious of Beck's commitment and advocacy efforts. Weeks before his argument to the Supreme Court, Beck told the St. Louis Bar Association that he heartily approved of the Dagenhart decision, and believed that if courts continued to sustain congressional taxation without inquiry into motive "little will be left of the rights of the State."245

The Court's final blow came on May 15, 1922. Bailey v. George $^{246}$ was dismissed for lack of jurisdiction and failure to exhaust all grounds for equitable relief. The Johnston case was determined to be moot, ${ }^{247}$ but in Drexel $v$. Bailey the Court ruled the Child Labor Tax unconstitutional. $^{248}$ Chief Justice Taft, notoriously pro-business, ${ }^{249}$ found that the law represented a penalty, not a tax, and thus the Court was not inquiring into Congress' motives: ${ }^{250}$

\section{Wood, supra n. 48, at 273.}

243. Id.

244. Id. at 274. Beck later wrote Taft:

[Y]ou may be surprised to know that, although I presented the Government's contention in the Child Labor Case as strongly as I was able, yet none who heard you deliver the opinion may have welcomed the decision more than I. Had the Court adhered tenaciously to the views of the late Chief Justice White in McCray v. United States, our form of government would have sustained a serious injury.

Id.

245. Wood, supra n. 48, at 269.

246. Bailey v. George, 259 U.S. 16, 20 (1922).

247. Atherton Mills v. Johnston, 259 U.S. 13, 16 (1922).

248. Bailey v. Drexel, 259 U.S. 20, 44 (1922).

249. Taft was notoriously pro-business as a Justice and politician. See Roderick M. Hills, Jr., The Federalist Capers, Legal Affairs, http://www.legalaffairs.org/printerfriendly.msp?id=820 (accessed Feb. 6, 2011).

250. Bailey, 259 U.S. at 36. "But there comes a time in the extension of the penalizing features of the so-called tax when it loses its character as such and becomes a mere penalty, with the characteristics of regulation and punishment.... The case 
[G]rant the validity of this law and all that Congress would need to do hereafter, in seeking to take over to its control any one of the great number of subjects of public interest ... would be to enact a detailed measure of complete regulation of the subject and enforce it by a so-called tax upon departures from it. ${ }^{251}$

Justices Brandeis and Holmes acquiesced in the majority's opinion, much to the surprise of child labor opponents. Justice Clarke dissented without an opinion. ${ }^{252}$ Congress' taxing power was now equally as impotent as its commerce power to legitimate federal legislation on child labor.

\section{FEDERAL ACTIVITY IN THE 1920's AND 1930's}

\section{A. The Twentieth Amendment}

Few today, other than professional historians, know about the intense struggle that raged during the 1920s and 1930s, ultimately unsuccessful, to pass a constitutional amendment giving Congress and the states power to limit or prohibit child labor under the age of eighteen. Similar to the defeat of the Equal Rights Amendment in the 1970 s and 1980s, the failure to pass a constitutional amendment marked a significant setback for a set of ideas and the groups advancing those ideas. A coalition of socially conservative groups, ${ }^{253}$ joined by some Catholics, were able to frame the debate in terms thatdivorced from the realities of child labor-resonated with many voters and political representatives. To its opponents, the proposed Twentieth Amendment was an assault on parental authority, states' rights and traditional American values.

before us cannot be distinguished from that of Hammer v. Dagenhart." Id. at 37-39.

251. Id. at 38 .

252. Id. at 44 .

253. The opposition included women's groups that had opposed the Nineteenth Amendment grant of suffrage to women, e.g., Sentinels of the Republic, The Woman Patriots, and other conservative organizations, such as the National Association of Manufacturers, the American Farm Bureau Federation, and some American Catholics. See Riva Siegel, She the People: The Nineteenth Amendment, Sex Equality, Federalism, and the Family, 115 Harv. L. Rev. 947, 947-948 (2002). See generally Bill Kauffman, The Child Labor Amendment Debate of the 1920s; or, Catholics and Mugwumps and Farmers, 10 J. Libertarian Stud. 139, 152 (1992) (describing federalism and states' rights issues in the consideration of the Twentieth Amendment). 
With the Supreme Court blocking any congressional statute, a constitutional amendment was the only possible path for federal intervention on child labor. Samuel Gompers, President of the American Federation of Labor (AFL), noted that "the Supreme Court deals with childhood exactly as it would deal with pig iron...[A] constitutional amendment is needed to complete the work quickly.",254 This idea had been previously floated; meetings had been held at AFL headquarters between Gompers, Florence Kelly of the National Consumers League, representatives of the National Child Labor Committee and others to discuss wording. ${ }^{255}$ Ultimately, the proposed amendment read:

Section 1. The Congress shall have power to limit, regulate, and prohibit the labor of persons under eighteen years of age.

Section 2. The power of the several States is unimpaired by this article, except that the operation of State laws shall be suspended to the extent necessary to give effect to legislation enacted by the Congress. ${ }^{256}$

Two days after the decision in Bailey v. Drexel, Representative Roy Fitzgerald of Ohio introduced a resolution in the House endorsing the proposed constitutional amendment. ${ }^{257}$ The forces favoring the amendment initially seemed formidable; all three political partiesRepublican, Democratic and Progressive-were officially in support. The proposed amendment had endorsement across the political spectrum, from conservatives like Massachusetts Republican Senator Henry Cabot Lodge to Progressive Senator Robert LaFollette. ${ }^{258}$ Nongovernmental groups like the National Child Labor Committee, the National Consumer Union and others had already had great legislative success in the states on child labor and allied issues. ${ }^{259}$ Each 1924 presidential candidate supported the measure. ${ }^{260}$ Proponents of the

254. Samuel Gompers, Let Us Save the Children, 29 Am. Federationist 413, 413414 (1922).

255. Marvin Levine, Children for Hire: The Perils of Child Labor in the United States 29 (Greenwood Publishing Group 2003).

256. 66 Cong. Rec. 3212 (1925).

257. Trattner, supra $\mathrm{n} .84$, at 162.

258. Kyvig, supra n. 80, at 257.

259. See supra $\mathrm{nn} .83-91$ and accompanying text.

260. Novkov, supra n. 63, at 374. 
amendment were optimistic about the possibility for early ratification and, indeed, the process in Congress was quick and decisive. By the summer of 1924, both the House (297-68) and the Senate (61-23) had approved the measure. ${ }^{261}$

Even at this early stage, however, it was clear that a powerful opposition was forming and a grab bag of negative arguments being collected that would ultimately doom the amendment. In hearings before congressional committees, employer groups challenged the appropriateness of federal action, arguing that regulation of child labor was best left to the states-even though employers actively opposed restrictions at that level. ${ }^{262}$ Another rhetorical gambit, drawn from common law principles, was the threat of loss of parental rights over children $^{263}$ to a power-hungry, and, in the future, socialist/communist government. The use of the phrase "labor of persons under eighteen ..." in Section 1 of the proposed amendment, rather than "employment" or "employment relations," provided fuel for a firestorm of arguments that parental authority was about to be supplanted by government and that children would no longer have the educational and disciplinary benefits inherent in work.

The proposed amendment would give to Congress the power to forbid any farm boy from milking a cow or even driving in a cow from the pasture until he is eighteen years old. Under its sweeping provisions it might and probably would be made illegal for sister Suzie to wash a dish or sew on a button until after her eighteenth birthday. ${ }^{264}$

And while the Palmer raids and the Red Scare of $1919-1920^{265}$ had abated by the mid-1920s, fear of a left-wing takeover of the United

261. LABOR: A 20th Amendment? Time Mag. (Jan. 5, 1925).

262. Joan Aldous, The Political Process and the Failure of the Child Labor Amendment, 18 J. Fam. Issues 71, 76 (1997).

263. "The state has no jurisdiction over the child merely because it is a child, and no earthly power can delegate such privilege to the state. The divine law, as well as the invincible law of nature, prescribed the rights and duty of parent and child centuries before nations were known and governments formulated." 66 Cong. Rec. 3212 (1925) (read from an article submitted by Senator King).

264. Trattner, supra $\mathrm{n}$. 84, at 284.

265. The legal and political developments during the "Red Scare" are described in Geoffrey R. Stone, Perilous Times: Free Speech in Wartime 220-226 (W. W. Norton \& Co. 2004). 
States remained strong, ${ }^{266}$ and the proposed amendment was branded as "communist." 267

Not least among the opponents to the amendment were the Sentinels of the Republic, the Women Patriots, and other groups that had played a significant role in the campaign against suffrage for women. These groups came together to resist what they saw as attempts to attack the traditional American home and family. ${ }^{268}$ Harriet Frothingham, a prominent Women's Patriots leader (and losing plaintiff in Frothingham v. Mellon ${ }^{269}$ ) expressed her opposition to proposed 1920s reforms as a triplet of socialist bills to cover education, maternity and infancy, and child labor; “...[T]he bills are different, but the backers are always the same, with the same objective, nationalized care, control, and support of mothers and children.,270 Equally as

266. This was a period of American and European intervention in the civil war going on in the former Tsarist Russian empire. The newly-emergent Bolshevik Revolution was seen as a threat to the existing economic and political order throughout Europe and North America. William D. Guthrey called the amendment a "communistic effort to nationalize children." William D. Guthrey, The Child Labor Amendment: Argument in Opposition to Ratification 36 (1924), quoted in Woodhouse, supra n. 53, at 1066.

267. The Citizens Committee to Protect Our Homes and Children called the Amendment a keystone in the Communist Program and the "brainchild" of Lenin's mistress. In 1933, the President of the American Bar Association called it "a communist effort to nationalize children ..." Kauffman, supra n. 253, at 140.

268. See Mustering Sentinels of the Republic! Natl. Magazine (Oct. 1922) (discussing leadership of the Sentinels of the Republic).

269. Cmmw. of Mass. v. Mellon, 262 U.S. 447, 487 (1923) (taxpayer lacked standing to bring suit to enjoin federal statute providing funding to reduce maternal and infant mortality).

270. 67 Cong. Rec. 12,919, 12,930 (1926). The Women's Patriots noted:

[it] has been shown that the "worst form of communism" as Senator Kingwell calls it, is found in the feminist phase of communism-arousing women against men, wives against husbands and providing community care for children, legitimate and illegitimate, to "remove the economic foundations of monogamous marriage.

Id. at 12,946. See generally Kauffman, supra n. 253 (describing issues of federalism and states' rights in debates over the proposed amendment). The President of the American Bar Association claimed that the Amendment was "a communistic effort to nationalize children, making them primarily responsible to the government instead of to their parents." Id. at 140. Congressman Fritz G. Lanham likewise mocked the Amendment as enjoining children to "obey your agents from Washington, for this is right. Honor thy father and thy mother, for the Government has created them but a little lower than the Federal agent. Love, honor, and disobey them." Jeffrey A. Tucker, The Trouble With Child Labor Laws, Mises Daily (Feb. 11, 2008). 
damaging to the campaign for enactment of the Child Labor Amendment was opposition from Catholic Church organizations and laypersons. Many in the clerical hierarchy and laity saw the proposal as a threat to parochial education and parental control over children. ${ }^{271}$

Despite quick and decisive approval of the amendment in Congress, ratification efforts in the states quickly ran into a buzz saw of opposition. A few states ratified quickly, but a defeat in Massachusetts proved decisive in 1924. Action in the Massachusetts legislature was deferred to provide a vote in a referendum, allowing opponents to organize effectively. In particular, the Catholic hierarchy in Massachusetts vigorously opposed the amendment as a continuation of initiatives in other states restricting parochial education and as an expression of the power of the resurgent Klu Klux Klan (KKK). ${ }^{272}$

Nor was the Massachusetts opposition simply composed of Catholics. The President of Harvard, A. Lawrence Lowell, was active in organizing establishment Protestants to oppose Congress' authority to regulate children in labor or education. ${ }^{273}$ Employers saw the amendment as choking off the supply of child labor. ${ }^{274}$ An even more ominous development in the Massachusetts referendum campaign was, for the first time in the history of the struggle to restrict child labor, explicit resistance from the American Farm Bureau Federation and other agricultural groups. ${ }^{275}$ This reflected concern that child labor, whether on small family farms or on the large corporate entities then transforming American agriculture, would become unavailable. Opposition from the agricultural interests was to prove critical in numerous coming battles. ${ }^{276}$

271. Woodhouse, supra $\mathrm{n}$. 53, at 1062.

272. See Kauffman, supra n. 253, at 144. The KKK's extreme anti-Catholic views prevented New York Governor Al Smith from being nominated for President on the Democratic ticket in 1924. The head of the Massachusetts Catholic Church, Cardinal O'Connell, was particularly wary of federal power, fearing Congress could pass a law subjecting schools and teachers to federal control and banning parochial schools. Aldous, supra n. 262, at 82 . In the run up to the 1924 Massachusetts referendum, Cardinal O'Connell instructed all pastors in his archdiocese to read a pastoral letter warning that the Child Labor Amendment would shift control over children to the federal government, reminiscent of Soviet Bolshevism. Id.

273. Kauffman, supra $\mathrm{n}$. 253, at 160.

274. Aldous, supra n. 262, at 83.

275. Id.

276. Farm groups opposed the ratification effort in the states of the Child Labor Amendment and later successfully lobbied against the inclusion of farm workers in 
The rhetoric of the anti-ratification campaign in Massachusetts and the organization of opposition groups proved wildly successful. The referendum resulted in a defeat by an almost three-to-one majority. ${ }^{277}$ Soon afterwards, New York's legislature tabled the amendment and by early 1925, only four of the state legislatures where the amendment was pending had approved it. The first wave of ratification action had resulted in a crushing defeat. The Child Labor Amendment was not to surface again until the depths of the Great Depression.

\section{B. Developments in the Great Depression}

With the nation mired in the greatest economic crisis of its history, and the newly-elected President Franklin Delano Roosevelt (FDR) promising a "New Deal," Congress passed the National Industrial Recovery Act (NIRA) in April 1933. ${ }^{278}$ The Act's purposes included re-employment of idle workers, creation of decent wages, and prevention of ruinous and unfair competition. Child labor was viewed as a significant factor in each of these economic problems. ${ }^{279}$ Under the NIRA, the President was authorized to approve "codes of fair competition" that would further the "public interest." 280 The codes set rules on trade practices, prices, wages and hours. ${ }^{281}$ Most of the codes prohibited children under eighteen from performing "hazardous work" and set minimum age requirements. ${ }^{282}$ The very first NIRA Code

protective New Deal labor statutes, such as the National Industrial Recovery Act, the Fair Labor Standards Act, the National Labor Relations Act, the Social Security Act, and others. See infra nn. 354-363 and accompanying text.

277. Aldous, supra n. 262, at 76.

278. Natl. Indus. Recovery Act, Pub. L. No. 67, Ch. 90, 48 Stat. 195, 196 (1933).

279. See Ella Arvilla Merritt, Trend of Child Labor, 1927-1936, Mthly. Lab. Rev. 1371, 1371 (Dec. 1937); see Margaret H. Schoenfeld, Analysis of the Labor Provisions of the N.R.A. Codes, Mnthly. Lab. Rev. 574, 574 (Mar. 1935).

280. Natl. Indus. Recovery Act, supra n. 278.

281. Over 7,000 such codes for different industries were developed. Violations of these negotiated codes constituted a criminal misdemeanor punishable by fine. Id.

282. Kyvig, supra $\mathrm{n}$. 80, at 307. By the end of 1933 more than 100 codes had been adopted; almost all banned employment under the age of sixteen. Id. at 308. The NIRA was responsible for blocking 100,000 child laborers under the age of sixteen from the work force. When the statute was declared unconstitutional, those children went back to work. See Fair Labor Standards Act of 1937: Joint Hearings on S. 2475 and H.R. 7200 Before the S. Comm. on Educ. and Labor and the House Comm. on Labor, 75th Cong. 1483-85 (1937) (remarks of Hon. Francis Perkins, Secretary of 
banned employment of children under sixteen in cotton textile mills, the venue for previous constitutional attacks on federal child labor limits. ${ }^{283}$

The Supreme Court, however, quickly moved to block many parts of the New Deal, including restrictions on youth employment. On "Black Monday," May 27, 1935, it declared the NIRA unconstitutional in A.L.A. Schechter Poultry Corp. v. U.S. ${ }^{284}$ The child labor provisions were not specifically at issue, but the High Court found the entire statute "attempted regulation of intrastate transactions" that affect interstate commerce "only indirectly." 285 The Agricultural Adjustment Act of 1933 (AAA), as amended in $1934,{ }^{286}$ allowed the Secretary of Agriculture to create child labor standards as a prerequisite to payment of federal benefits to growers of beet and sugar cane, crops where child labor was particularly omnipresent. The Court held that statute unconstitutional in 1936 in U.S. v. Butler. ${ }^{287}$ When the AAA was in force, child labor in the sugar beet fields was sharply reduced, but after the statute's invalidation, large numbers of children under fourteen returned to work. $^{288}$ As a result of the High Court's decisions in 1935 there was a $55 \%$ increase from the previous year in employment of fourteen- and fifteen-year-olds. Two and one-half times as many children left school in 1936 to take low income jobs as in the previous year. ${ }^{289}$

Labor).

283. The impact of the NIRA on the cotton mills, scene of the prior litigation on the constitutionality of federal child labor restrictions was particularly noteworthy. See supra n. 282 and accompanying text. See also Andrew J. Samset, Child Labor and the New Millennium, 21 Whittier L. Rev. 69, 75 (1999).

284. A.L.A. Schechter Poultry Corp. v. U.S., 295 U.S. 495, 521 (1935) (upholding a Second Circuit decision that held unconstitutional wage and hours provisions regulating the wholesale poultry trade because Schechter's Market was not in interstate commerce).

285. Id. at 551. The court also found the Act was an unconstitutional delegation of legislative power to the President because it provided no standards to be administratively applied. Id.

286. Agricultural Adjustment Act, Pub. Law No. 73-10, 48 Stat. 31 (1933) (as amended May 9, 1934, 48 Stat. 670).

287. U.S. v. Butler, 297 U.S. 1, 68 (1936) (holding states have the power to regulate agriculture, and Congress could not indirectly accomplish the AAA goals by taxing and spending to purchase compliance on matters in excess of its Commerce Clause powers).

288. Trattner, supra n. 84, at 210.

289. George E. Paulsen, A Living Wage for the Forgotten Man 67 (Susquehanna U. 
Judicial invalidation of New Deal laws, including restrictions of child labor, helped to create a referendum on President Roosevelt's policies in the 1936 national elections. The result was unequivocal; Roosevelt received 523 electoral votes to eight for Alf Landon, and Democratic control of Congress was strengthened. ${ }^{290}$ Emboldened by this national vote of confidence, FDR moved quickly after his second inauguration in 1937. Roosevelt's "court packing plan" proposed legislation to increase the size of the Supreme Court by one for each sitting Justice over age seventy, up to a maximum of fifteen Justices. ${ }^{291}$ The proposal, however, drew intense opposition, including from Democrats concerned about the independence of the federal judiciary. ${ }^{292}$ It never came to a final congressional vote.

But, by the spring of 1937, Supreme Court decisions reflected different views on a number of key constitutional issues. In West Coast Hotels v. Parrish, ${ }^{293}$ the Court approved a state statute requiring minimum wages for women, a retreat from its prior position on state protective labor legislation. The Supreme Court similarly upheld the constitutionality of the federal National Labor Relations $\mathrm{Act}^{294}$ against the argument that it regulated manufacturing, a matter constitutionally reserved to state authority by prior Court precedent. ${ }^{295}$ Since the manufacture of steel and other products was now deemed to be in the "flow" of interstate commerce, it was evident that previous negative rulings on Congress' statutory power to restrict child labor ${ }^{296}$ might be overruled in future cases.

Press 1996).

290. Marian C. McKenna, Franklin D. Roosevelt and the Great Constitutional War: The Court Packing Crisis of 1937243 (Fordham U. Press, 2002). The 1936 election was the most lopsided electoral victory in the history of American presidential contests. Id.

291. Chemerinsky, supra n. 87 , at 255-256.

292. Id.

293. See 300 U.S. 379, 386 (1937).

294. See Jones v. Laughlin Steel Corp., 301 U.S. 1, 47 (1937).

295. See e.g. A.L.A Schechter Poultry Corp. v. U.S., 295 U.S. 495, 551 (1935) (finding NIRA unconstitutional as violation of state control of local industry); U.S. v. E.C. Knight Co., 156 U.S. 1, 12 (1895) ("[c]ommerce succeeds to manufacture and is not a part of it.")

296. See e.g. Hammer, 247 U.S. at 273. 


\section{The FLSA}

The country was, by 1937 , overwhelmingly opposed to child labor; public opinion polls showed a large majority in favor of the Child Labor Amendment. ${ }^{297}$ Reformers saw their opportunity and a number of political-legal approaches were proposed. Some, in and out of the administration, favored aggressively pushing for passage of the Child Labor Amendment. Low wages, adult unemployment, depressed consumer spending and massive child labor had created a new burst of activity on the proposed Twentieth Amendment in the 1930s; by 1937 twenty-eight states had ratified the amendment, leaving it just eight short of passage. ${ }^{298}$ Labor Secretary Perkins ${ }^{299}$ and others ${ }^{300}$ believed only this solution could ultimately solve the problem. These forces believed child labor needed to be eliminated from both intrastate and interstate employment, which could only be accomplished by a constitutional amendment.

Other leaders endorsed the idea of a separate federal statute dealing exclusively with youth workers to avoid the political complexities created by the general wage and hour provisions, as well as administrative issues arising from the proposed FLSA. ${ }^{301}$ Senator

297. Paulsen, supra n. 289, at 65. "Public opinion polls revealed that substantial majorities favored national regulation of labor standards, with 68 percent favoring an 8 -hour day, 63 percent supporting minimum wages, and 82 percent favoring a childlabor amendment." Id.

298. Novkov, supra n. 63, at 395. Hold-outs included almost all of the south, except for Kentucky and Arkansas. Id.

299. Paulsen, supra n. 289, at 86-87. At joint congressional hearings, Perkins testified that the child labor prohibition in the proposed FLSA was commendable, but she still favored the Child Labor Amendment. Id. Perkins asked Roosevelt to delete the child labor ban from the comprehensive labor standards bill, but Roosevelt refused in order to make the labor standards measure easier to get through Congress. Id. at 77 .

300. Id. at 90. Chief of the Children's Bureau, Katherine Lenroot, likewise testified that since the NIRA's invalidation the number of children working had risen sharply and many were employed in intrastate industries. Id. Because any proposed statutory prohibition would only cover a small number of working children she continued to urge passage of the Child Labor Amendment. Id. AFL President William Green, after commenting on conditions in New Jersey silk mills employing thirteenand fourteen-year-olds, said ratification of the Child Labor Amendment was the only solution. Id. at 67.

301. After an extensive question-and-answer session with Senator Black on the FLSA, Senator Edwin Johnson (Colorado) noted:

The real question before the Senate is: Shall it consider the very important child-labor problem in a separate bill.... Why should the Congress inject 
Barkley (D. Ky.) sponsored the Childrens' Bureau bill dealing solely with child labor. ${ }^{302}$ Others, however, including FDR himself, believed that child labor issues should be part of the overall labor bill that ultimately became the Fair Labor Standards Act. ${ }^{303}$ This was ultimately the strategy that prevailed.

The story of the battle to enact the general wage and hour provisions of the FLSA has been well-told elsewhere. ${ }^{304}$ The child labor provisions were a side show in the general struggle for passage, but decisions made during this battle have impacted the history of child labor in the United States to this day. On May 24, 1937, President Roosevelt recommended that Congress pass legislation establishing national labor standards. In addition, Roosevelt noted, "a selfsupporting and self-respecting democracy can plead no justification for the existence of child labor." 305

That same day the FLSA was introduced by Senator (later Supreme Court Justice) Hugo Black (D. Ala.) and Representative Connery (D. Mass.). The bill provided for national regulation of

the regulation of child labor, which is relatively simple, into all the complexities and uncertainties of the wage and hour bill? Is it possible that child labor has been added to this wage and hour bill to obtain public sympathy for a program over which there is great difference of opinion and controversy. ... [ [I]t is not fair. . . .

82 Cong Rec. 7633-68 (1937).

302. Paulsen, supra n. 289, at 77.

303. See generally Franklin D. Roosevelt et al., The Public Papers and Addresses of Franklin D. Roosevelt: The Constitution Prevails Vol. 6, 209-218 (The Macmillan Co. 1941).

The reason the child labor section was included with the wage and hour legislation instead of forming a separate act was because of the feeling that it had a better chance to be declared constitutional as an integral part of general legislation intended to remove the burden of unfair labor practices on the free flow of interstate commerce. Alone, child labor may not be a very great burden, but when considered with the other factors, it has a better chance of surviving attack in the courts.

John S. Forsythe, Legislative History of the Fair Labor Standards Act, 6 L. \& Contemp. Probs. 464, 487 (1939).

304. See generally Forsythe, supra n. 303; Paul H. Douglas \& Joseph Hackman, The Fair Labor Standards Act of 1839, I, 53 Political Sci. Q. 491, $491-492$ (1938) [hereinafter Douglas \& Hackman I].

305. Roosevelt, supra n. 303, at 210-212 (citing the dissent in Hammer v. Dagenhart, Roosevelt declared that the power of Congress over interstate commerce gave it power over child labor). 
wages, hours and other conditions of employment ${ }^{306}$ and banned "oppressive child labor," i.e., employment of children under the age of sixteen or between sixteen and eighteen in "hazardous occupations.",307 These youth employment provisions approximated the 1916 KeatingOwen Act and the 1919 Child Labor Excise Tax enactment. The congressional battle for passage of the FLSA was lengthy, lasting more than a year and encompassing two regular, and one special, sessions of Congress. It was also procedurally and politically extraordinarily complex.

As the bill worked its way through the House of Representatives, the child labor sections varied. ${ }^{308}$ The original provisions were progressively weakened; fourteen- and fifteen-year olds not working in manufacturing and mining were now permitted to work except under "oppressive" conditions. ${ }^{309}$ This, of course, opened the door for employment of under-sixteen-year-olds until the present day. Sixteenand seventeen-year-olds were allowed to work in all but "particularly hazardous" occupations. ${ }^{310}$ Administration of the child labor provisions was placed in the Children's Bureau. ${ }^{311}$

Despite concessions on these and other issues, the House Rules Committee, dominated by Southern Democrats and Republicans, blocked consideration of the entire measure, preventing any action during the first regular session of the 75th Congress. In response,

306. Douglas \& Hackman I, supra n. 304 , at $493-499$ (The administration bill proposed to give a broad mandate to an Administrative Board with powers over labor and management. It would set minimum wages, maximum hours, and a host of other provisions. The Board was to be composed of five men appointed from civil-service lists and confirmed by the Senate. The Board would appoint a director for each state. Hearings were to be conducted locally. Before determining minimum wages and maximum hours the Board was required to receive advice from a committee representing labor, industry and the public and also to provide notice and hearings for interested parties. Criticism of this administrative approach included claims that it had the broadest government authority granted, in peace-time, to a person(s) other than the President).

307. Id. at 504-506.

308. Id. at 497 .

309. Section 203(1) of the Act allowed employment of fourteen- to sixteen-yearolds if the Secretary of Labor determined such work was confined to periods which "will not interfere with their schooling and to conditions which will not interfere with their health and well-being." 29 U.S.C.S. § 203(1) (2010).

310. Douglas \& Hackman I, supra n. 304, at 497.

311. Paul H. Douglas \& Joseph Hackman, The Fair Labor Standards Act of 1938, II, 54 Political Sci. Q. 29, 52 (1939) [hereinafter Douglas \& Hackman II]. 
President Roosevelt called a special session to begin November 15, 1937, but the bill was stalled there as well by the same conservative coalition. ${ }^{312}$

In the second regular session of the 75th Congress, Roosevelt agreed to significant changes in labor standards in an attempt to appease southern Democrats. ${ }^{313}$ The child labor provisions remained a "sweetener" to help ensure passage of the Act. ${ }^{314}$ In the end, the critical events driving passage of the FLSA were probably more explicitly political. Soon after the victory of two New Deal supporters in Spring 1938 primaries, ${ }^{315}$ a petition to discharge the bill from the Rules Committee, where it had again been bottled up, obtained the needed 218 signatures in less than three hours. Within a few weeks the House voted 291 to 89 in favor of the FLSA, and it was passed by the Senate without a record vote.

\section{The Impact of the FLSA on Child Labor}

The impact of the FLSA's passage on the use of child labor, however, was negligible. The Supreme Court itself quickly recognized the Act's limited reach. In Western Union Telegraph Co. $v$. Lenroot,${ }^{316}$ it narrowly construed the statute to exclude transmission of telegraph messages from the ban on a producer's shipment of "goods" in interstate commerce. The Court noted: "[s]o far as coverage was concerned, all proponents were aware that any of the suggested versions of legislation would reach only a small fraction of existing child labor."317

312. Douglas \& Hackman I, supra n. 304, at 508-511.

313. Id. at 514-515.

314. Felt, supra n. 28, at 474-475. The President believed he would "get more votes from conservative Congressmen if the wage and hour provisions [were] ... made more palatable by integration with child labor." Id. Senator Wheeler noted child labor "was put on the bill ... because it was desired to say to senators, "When you vote against this bill your are also voting against the prohibition of child labor." Id.

315. Douglas \& Hackman I, supra n. 304, at 511-512 (on January 4, 1938, in the Alabama Democratic primary, Senator Lister Hill, a supporter of the FLSA and other New Deal legislation, won a decisive two to one victory against the anti-New Deal candidate. On May 3, 1938, Senator Claude Pepper, another pro-FLSA candidate, handily defeated his opponent in Florida).

316. 323 U.S. 490, 502-503 (1945).

317. Id. at $495-496$. 
Soon after passage of the FLSA, the United States entered World War II and even the limited child labor protections were eviscerated. When a labor shortage emerged as males entered the armed services, women entered the work force in large numbers ${ }^{318}$ but youth were affected even more dramatically. According to the Department of Labor (DOL), "[c]ontrary to general belief, the early withdrawal of boys and girls from school was a greater factor in the expansion of the labor force than was the increase in the number of women working."319 Following the outbreak of the war, school enrollment fell by $24 \%$ for fifteen- to eighteen-year-olds, while the number of fourteen- to seventeen-year-olds employed increased by $200 \%{ }^{320}$ By 1945, U.S. Census samples showed approximately 3.5 million youths employed full- or part-time, three to four times the number in $1940 .^{321}$

Further, in 1942 the Secretary of War requested that the DOL provide an exemption to the eighteen-year-old minimum age limit for hazardous occupations, which the DOL granted. ${ }^{322}$ Work accidents involving children rose $100 \%$ from 1942 to $1943 .{ }^{323}$ The increase both to the rise in the number of children employed and to the sharp increase in children employed in hazardous jobs. ${ }^{324}$ Presaging modern trends, the type of work performed by young people during the war shifted from primarily agriculture to a balance between farming, manufacturing, and services. ${ }^{325}$

The weaknesses of the child labor provisions of the FLSA were

318. Bureau of Lab. Statistics, U.S. Dept. of Lab., Sources of Labor Supply for the War, 57 Mthly. L. Rpt. 212, 212-213 (1943).

319. Id. at 212.

320. Natsuki Aruga, "An' Finish School": Child Labor During World War II, 29 Lab. History 498 (1988) (school enrollment for fifteen- to eighteen-year-olds fell by 1.2 million, and employment of fourteen- to seventeen-year-olds increased by over two million).

321. Bureau of Lab. Statistics, U.S. Dept. of Lab., Teen-Age Youth in the Wartime Labor Force, 60 Mthly L. Rpt. 6, 8 (1945) [hereinafter Teen-Age Youth in Wartime Labor]. Nationally, youth not attending school worked an average of forty-six hours per week. Id. at 15.

322. Aruga, supra n. 320 , at 519.

323. See id. at 498.

324. See id. at 512.

325. Teen-Age Youth in Wartime Labor, supra n. 321, at 11. In April 1944, six times as many workers between the ages of fourteen and seventeen worked in manufacturing, and over seven times more worked in service jobs than in 1940. Aruga, supra n. 320, at 509. 
apparent from the outset. Some deficiencies were, and are, apparent from the face of the statute itself, e.g., exclusions from coverage, allowance of work by most fourteen- to eighteen-year-olds, and lack of effective administrative resources or remedies for injured working youth. ${ }^{326}$ The safety and health issues were particularly egregious. Previous decades had produced a lengthy and richly documented history of death, injury, and disease produced by child labor. ${ }^{327}$ These issues were fully discussed at the FLSA committee hearings, but the statute did not mandate any reporting of work-related injuries and deaths, safety training for youth workers, or adult supervision. Other problems, such as lack of administrative enforcement, only became evident later.

Despite its symbolic importance, the FLSA's actual effect upon child labor in the United States was slight. Contemporary writers estimated only $30-50,000$ youth workers under sixteen were covered out of a total of 850,000 non-farm children then employed. ${ }^{328}$ In addition, 1930 Census data indicated one-half million worked on farms; these were entirely excluded from the Act. ${ }^{329}$ Historian Jeremy Felt estimated only $25 \%$ of youth in non-agricultural occupations and only $6 \%$ of the total number of under-sixteen-year-old workers were affected by the passage of FLSA. ${ }^{330}$ Children in industrial agriculture, intrastate industries, the street trades, messenger and delivery service, stores, hotels, restaurants, beauty parlors, bowling alleys, filling stations, garages, et cetera, were outside the law. ${ }^{331}$ Even worse, the law did not apply to many sectors of the economy where the most dramatic abuses of child labor were concentrated. ${ }^{332}$

326. See infra nn. 344-345 and accompanying text (no private right of action under the FLSA for children injured while working in violation of federal law).

327. See supra nn. 99-103 and accompanying text (congressional study of female and child labor produced nineteen volumes of reports and data on the problems produced by employment of theses groups).

328. Katharine Du Pre Lumpkin, The Child Labor Provisions of the Fair Labor Standards Act, 6(3) L. \& Contemp. Probs. 391, 405 (1939). The Act did “... not begin to deal with child labor as a mass problem. It touches at best 6 percent of these younger employed children." Id.

329. See infra nn. 351-352 and accompanying text.

330. Felt, supra n. 28, at 477-478.

331. See Du Pre Lumpkin, supra n. 328, at 402-403; Jonathan Grossman, Fair Labor Standards Act of 1938: Maximum Struggle for a Minimum Wage, 101 Mthly Lab. Rev. 22, 29 (1978).

332. See Du Pre Lumpkin, supra n. 328, at 402-403. 
In this regard, the FLSA followed the pattern of previous federal child labor restrictions, which likewise had little practical impact. The 1916 Keating-Owen Act had excluded most workplaces where youth workers were concentrated ${ }^{333}$ and there had been little enforcement against employers. ${ }^{334}$ The NRA Codes in the Great Depression applied principally to specified industrial facilities where youth were often absent. ${ }^{335}$ Similarly, the child labor provisions of the WalshHealey Public Contracts Act of $1937^{336}$ and Sugar Act of $1937^{337}$ were directed at relatively small pockets of child labor.

Aside from exclusions from coverage, the FLSA failed to effectually control child labor between the ages of fourteen and eighteen. The Act bans "oppressive child labor," 338 but the definition varies with the age of the child, the industry, the type of job, parental involvement, schooling and other factors. While sixteen is the usual minimum age for employment, the Act lowers the minimum age to fourteen in many cases. ${ }^{339}$ The FLSA provided no authority to regulate the number of hours or the time sixteen- and seventeen-yearolds could work. ${ }^{340}$ These adolescents may be compelled to work long hours and late into the night, conditions almost certain to impair their studies. When all these exemptions are tallied, millions of American children are working legally today. ${ }^{341}$

Lack of meaningful remedies was another significant deficiency.

333. See supra $\mathrm{nn}$. 104-110 and accompanying text.

334. See supra nn. 104-110; Katharine Du Pre Lumpkin \& Dorothy Wolff Douglas, Child Workers in America 61 (Robert M. McBride \& Co. 1937).

335. See Felt, supra n. 28, at 473.

336. 41 U.S.C.S. $\S 35(2010)$.

337. Pub. L. No. 75- 414, § 301, 50 Stat. 903, 909 (1937).

338. 29 U.S.C.S. $\S \S 203,212$ (2010); see 29 C.F.R. $\$ 570.102(2010)$.

339. 29 C.F.R. $\S 570(a)(1)(i)$ ("...employment is confined to periods which will not interfere with their schooling and to conditions which will not interfere with their health). The Regulation restricts youth between fourteen and fifteen years of age to no more than three hours of work per day and eighteen hours of work per week when school is in session. 29 C.F.R. at $\S 570.35$. However, many youth work far more hours.

340. See Schmidt v. Reich, 835 F.Supp. 435, 444 (N.D. Ill. 1993).

341. Ctrs. for Disease Control and Prevention, Young Workers Safety and Health, Selected Charts on Young Worker Employment, Injuries and Illnesses, Figure 2, http://www.cdc.gov/niosh/topics/youth/chtpkgfig2.html (accessed Feb. 7, 2011). In 2007, there were 2.6 million employed youth between fifteen and seventeen years of age. Id. 
Primary reliance was placed on criminal sanctions, but not one prosecution was ever brought. ${ }^{342}$ The combination of a heightened mental requirement, need for a repeat offense, and the minimal sanction quickly rendered criminal enforcement useless. ${ }^{343}$ The Act's civil sanctions were similarly toothless. No civil penalties were included for violations. Individuals and the agency were given the right to pursue claims for unpaid minimum wage or overtime, ${ }^{344}$ but only the DOL may enforce the safety and health provisions of the FLSA. Enforcement by the parties most likely to bring suit-an injured youth and their families-is thus unavailable. ${ }^{345}$

Moreover, administrative enforcement of the child labor provisions was almost non-existent from the beginning. Only $\$ 50,000$ was appropriated for the Children's Bureau in 1939 to enforce the child labor provisions. ${ }^{346}$ The Wage and Hour Division, given jurisdiction to administer the general wage and hour provisions, had twenty-three inspectors in 1939, despite the fact that 603 were estimated to be needed. ${ }^{347}$ Given a workforce of approximately one million children, and the agency's responsibility for adult conditions of employment, it was apparent from the outset that there would be little or no

342. Ran LEXIS terms and connectors search of the following: "29 pre/5 216a" retrieving sixteen results, none of which dealt specifically with child labor law violations (last search Sept. 12, 2008).

343. Darby v. U.S., 132 F.2d 928, 930 (5th Cir. 1943) (conviction requires "deliberate, voluntary and intentional" conduct, or actions with reckless indifference to, or disregard for, the Act's requirements). "Willfulness is deliberate and purposeful failure to comply with Fair Labor Standards Act." Id. Violation is willful if act of "defendant is deliberate, voluntary, and intentional"; mere mistakes or inadvertency is insufficient to show willfulness. Nabob Oil Co. v. U.S., 190 F.2d 478, 480 (10th Cir. 1951). "Violation is willful only if employer knew or showed reckless disregard as to whether its conduct was prohibited." Brock v. Richland Shoe, 779 F.2d 80, 83 (3d Cir. 1986).

344. 29 U.S.C.S. $\S \S 216(b)(2010), 29$ U.S.C.S. $§ \S 216(c)(2010)$ (provides employees with a cause of action for back wages, liquidated damages, attorney's fees, and litigation costs). $\S 216(\mathrm{~b})$ provides for a jury trial. Lorillard v. Pons, 434 U.S. 575, 580 (1978). Liquidated damages are calculated by doubling the amount of unpaid minimum wages or overtime awarded to the plaintiff. See e.g. Coston v. Plitt Theaters, 831 F.2d 1321, 1328-1330 (7th Cir. 1987), cert. denied, 485 U.S. 1007 (1988) (ADEA case following FLSA precedent).

345. See e.g. Henderson v. Bear, 968 P.2d 144, 146 (Colo. App. 1998) (finding FLSA violations provide no basis for implying private cause of action).

346. Paulsen, supra n. 289, at 135.

347. Id. 
enforcement. And after a year of operation, the Children's Bureau had managed to hold just one hearing on the need for the promulgation of Hazardous Orders, critical for improving health and safety. ${ }^{348}$ This administrative lethargy proved to be a harbinger of the future lack of enforcement.

\section{E. The Agricultural Exclusion}

One of the most important exclusions from coverage by the FLSA - that of agricultural workers-reflected structural factors in American public life that go to the heart of efforts to produce social change in any period. The FLSA's treatment of farm workers reflected the complicated and interwoven effect of ideology, economic and political power, and our own "American Dilemma"-race. ${ }^{349}$ The administration's 1937 proposed bill excluded agriculture and contained, in the sponsor's own words, "the most comprehensive definition of agriculture ever formulated." 350

348. Du Pre Lumpkin, supra n. 328, at 396-397. The only hearing concerned the explosives industry.

349. See generally Gunnar Myrdal, An American Dilemma: The Negro Problem and American Democracy 809 (Harper \& Row 1944). Myrdal's study of race relations in America detailed the obstacles to full participation in American society of AfricanAmericans. Id. The "dilemma" of the title referred to the coexistence of American liberal ideals and the denial of civil, economic, and political rights to AfricanAmericans. $I d$. at 794 . The "negro problem" was ultimately a white man's problem. $I d$. at 587.

350. 81 Cong. Rec. 7648 (1937) (statement of Senator Black, Chief Senate sponsor of the FLSA). Section 3(f) of the FLSA contained the following definition of agriculture:

"Agriculture" includes farming in all its branches and among other things includes the cultivation and tillage of the soil, dairying, the production, cultivation, growing and harvesting of any agricultural or horticultural commodities (including commodities defined as agricultural commodities in section $15(\mathrm{~g})$ of the Agricultural Marketing Act, as amended), the raising of livestock, bees, fur-bearing animals, or poultry, and any practices (including any forestry or lumbering operations) performed by a farmer or on a farm as an incident to or in conjunction with such farming operations, including preparation for market, delivery to storage or to market or to carriers for transportation to market.

Pub. L. No. 75-718, $\S 3(f), 80$ Stat. 833, 833-834 (codified as amended at 29 U.S.C. $§ 203(f)(1982)$ ). This broad exclusion included any "practice incident to farming." Id. 
Congress was fully aware that by 1930 agriculture was "the most serious child labor problem in the United States, ${ }^{, 351}$ employing $61 \%$ of all child workers ten- to sixteen-years old, and $87 \%$ of children aged ten to fourteen. ${ }^{352}$ At the time of the initial passage of the FLSA in 1938, farm laborers-adult and youth-were among the poorest workers in the country and they remain so today. ${ }^{353}$ Their exclusion from the FLSA is explained at one level by simple political reality. Two key voting blocs - farm state and southern Congressmen-would have torpedoed any labor reform measure that included workers in those sectors. ${ }^{354}$ As Representative Hartley commented:

Political expedience rather than relief for the exploited workers of America has dictated the terms of this bill ... [W] hy is it that the poorest paid labor of all, the farm labor ... has been omitted from this bill? The answer is that the votes of the farm block in the House, the best organized

351. Davin Curtiss, The Fair Labor Standards Act and Child Labor in Agriculture, 20 J. of Corp. L. 303, 309 (1994-1995).

352. Id.

353. A U.S. Dept. of Agriculture Study showed that the annual average wage for farm workers between $1935-1939$ was $\$ 410$ without board and $\$ 312$ with board at that time. This sum was approximately one-half of the minimum wage of $\$ 806$ per year set by the FLSA. According to the most recent National Agricultural Workers Survey (NAWS), the 2000-2001 median family income for farm workers (including income from all sources, not just farm work) was in the range of $\$ 15,000-\$ 17,499$ per year, or $\$ 288-\$ 337$ in gross wages per week. Thirty percent of all farm workers, according to NAWS, had total family incomes below the poverty line. Dept. of Lab., A Demographic and Employment Profile of United States Farm Workers, Findings from the National Agricultural Workers Survey 2001-2002 xi, http://www.doleta.gov/agworker/report9/naws_rpt9.pdf (March 2005).

354. 83 Cong. Rec. 9257 (1938). Historian Carey McWilliams noted that farm workers were historically excluded from political centers of power and that [m]ost of our social legislation has been enacted as the result of a political 'deal' between organized labor and farm groups. The basis of this deal has always been 'we the farm representatives' will not object to this legislation, if you, the representatives of organized labor, will agree to exempt farm employees.

Carey McWilliams, Farm Workers and "Dirt Farmers" Need Power, in New Deal Thought 251, 254-255 (H. Zinn ed., Hackett Publishing Co. 1965). In addition, Southerners dominated Congress and controlled key committees essential to enactment of President Roosevelt's progressive statutes. They were intent on protecting the existing Jim Crow economy in the South and its attendant white supremacist ideology. Marc Linder, Farm Workers and the Fair Labor Standards Act: Racial Discrimination in the New Deal, 65 Tex. L. Rev. 1335, 1351 (1987). 
block we have here, would have voted against the bill and defeated it. ${ }^{355}$

The exclusion of agricultural workers was also a reflection of the power wielded by large agricultural interests in Congress and state legislatures. Lobbyists from The Grange, The Farm Bureau Federation, and other organizations representing big agribusiness were ubiquitously present during hearings and other legislative processes in the passage of the FLSA. ${ }^{356}$ These organizations argued farmers could not afford to pay minimum wages or comply with safety regulation. Such requirements "would make it virtually impossible for the farmer to secure hired help within his reach." 357

Abandonment of agricultural workers, including children, in the FLSA was part of a larger legislative pattern excluding them from numerous other protective statutes. ${ }^{358}$ A number of factors combined to produce this result. Ideology was at work; from the founding of the Republic, work on farms was idealized as healthful, educational, and an example of the uniquely American spirit. ${ }^{359}$ In 1910, in proposing a bill to limit child labor, Senator Albert Beverage noted that his intent was not to "strike at the employment of children engaged in agriculture. I do not pretend that working children on the farm is bad for them." 360 State child labor statutes passed during the Progressive Era routinely excluded farm work. ${ }^{361}$ Indeed, as the anti-child labor

355. 83 Cong. Rec. 9257 (1938).

356. Curtiss, supra n. 351, at 305; see Patrick M. Anderson, The Agricultural Employee Exemption from the Fair Labor Standard Act of 1938, 12 Hamline L. Rev 649,656 (1989).

357. 82 Cong. Rec. 1477 (1937).

358. The Keating-Owen Act did not cover farm labor and the National Labor Relations Act likewise excluded agricultural labor from its protection of union organization and collective bargaining. 29 U.S.C.S. 142(3) (2010). For a detailed description of the exclusion of agricultural laborers from the FLSA, reference Anderson, supra $\mathrm{n} .356$.

359. Trattner, supra $\mathrm{n} .84$, at 149. In 1785, Thomas Jefferson declared that "[c]ultivators of the earth are the most valuable citizens. They are the most vigorous, the most independent, the most virtuous, and they are tied to their country and wedded to its liberty and interests by the most lasting bonds." The Jefferson Monticello, Jefferson, Quotations on Agriculture, http://www.monticello.org/site/jefferson/quotations-agriculture (accessed Feb. 7, 2011).

360. Trattner, supra n. 84, at 149.

361. See e.g. N.Y. Labor L. $§ 130$ (1923) ("no child under 14 years of age shall be employed in...any factory, mercantile establishment, business office ... or in the 
movement in the cities strengthened, more youths seem to have become employed in agriculture. ${ }^{362}$

But more was at work than the importance of cheap labor and the Myth of the American Farmer. Race was, and continues to be, a decisive factor. In many areas of the country, particularly in the South, African-Americans were concentrated in agricultural labor and domestic work, sectors explicitly left out of New Deal legislation. Black share-croppers were an important source of southern farm production; ${ }^{363}$ providing minimum wage coverage to them and to black domestic workers would have upset the existing Jim Crow socioeconomic hierarchy in these states. "[T]he primary ...beneficiaries of the exclusion were the large agricultural employers of the South (and of California) who depended upon a cheap supply of minority labor, much as they had depended upon slave labor before 1865."364 Blacks worked in conditions of near peonage, ${ }^{365}$ reflecting the political and legal hierarchy.

Bourbon aristocracy had resumed power in the southern states after their agreement to back Rutherford B. Hayes, the Republican candidate in the disputed 1876 presidential race. They now ruled the political-economic-social life of the former Confederacy and had succeeded in almost completely disenfranchising and subordinating African-Americans, often the majority of the population in many political units. Southern states had rewritten their constitutions to deny blacks - and often poor whites as well-the right to vote. ${ }^{366}$ Post-Civil War Amendments and statutes notwithstanding, the High Court had

distribution or transmission of merchandise, articles or messages, or in the sale of articles"); Trattner, supra $\mathrm{n} .84$, at 148-149.

362. See Trattner, supra n. 84, at 153; Du Pre Lumpkin \& Wolff Douglas, supra $\mathbf{n}$. 334 , at 61 (more than 500,000 youths were working in agriculture in 1930).

363. White planters preferred black to white sharecroppers because they could get more work out of the blacks for less pay. Representatives in Congress blocked any effort to change the Jim Crow status quo. Risa L. Goluboff, The Lost Promise of Civil Rights 7 (Harvard U. Press 2007).

364. Linder, supra n. 354, at 1337-1338.

365. Aside from the existing exploitative rural sharecropper system, AfricanAmericans from all over the country were enticed during the 1930's by the federal government's United States Employment Service to Southern farm jobs, such as those offered by the huge United States Sugar Company where they worked under conditions of virtual slavery. Goluboff, supra n. 363, at 7-8, 139-140.

366. John Hope Franklin \& Alfred A. Moss, Jr., From Slavery to Freedom, A History of African Americans 286 (1947). 
placed its imprimatur on southern white supremacy in cases interpreting federal civil rights laws and state-sponsored segregation. ${ }^{367}$ The disenfranchisement of blacks was legitimated in 1903 by Giles v. Harris, ${ }^{368}$ when the Supreme Court dismissed a suit on behalf of 5,000 black citizens of Alabama purged from the voting rolls as a result of the imposition of the various clauses of the new Alabama Constitution. ${ }^{369}$ In a shocking abdication of judicial power, Justice Oliver Wendell Holmes' majority opinion argued that federal equity had no power to require local officials to allow the black plaintiffs to register. ${ }^{370}$

As a result of Giles and subsequent cases involving the same plaintiffs, ${ }^{371}$ literacy tests, property and poll tax requirements, "grandfather" clauses, and similar techniques were used for decades to disenfranchise African-Americans throughout the South. ${ }^{372}$ Indeed, it was not until Smith v. Allwright, ${ }^{373}$ more than forty years after Giles, that the Supreme Court got around to deciding that the rules of the Democratic Party of Texas excluding African-Americans from participating in the party primary, the only significant election in most southern states, was a violation of the Fifteenth Amendment. ${ }^{374}$

The disenfranchisement of southern blacks had a direct effect on the provisions of federal statutes such as the FLSA. As political science Professor V.O. Key, Jr. explained in his classic 1949 work, Southern Politics: ${ }^{375}$

367. See e.g. Plessy v. Ferguson, 163 U.S. 537, 550-552 (1896) (upholding state and local white supremacist laws); The Civil Rights Cases, 109 U.S. 3, 61-62 (1883) (holding unconstitutional the 1875 Civil Rights Act).

368. See 189 U.S. 475, 486-493 (1903).

369. The Alabama constitutional provisions used to exclude black voters included the "good character and understand" clause. Id. at 483.

370. Rather, legislative relief was necessary because simply registering blacks under a flawed system would not cure the alleged fraud. Id. at 487-488.

371. See Giles v. Teasley, 193 U.S. 146, 162-163 (1904) (suit seeking damages for refusal to register black voters dismissed).

372. Franklin \& Moss, supra n. 366, at 283.

373. 321 U.S. 649 (1944).

374. Id. at 663-664; see Terry v. Adams, 345 U.S. 461, 494 (1953) (holding that a private political organization called the Jaybird Democratic Party could not exclude blacks from its primaries on racial grounds).

375. Robert K. Fleck, Democratic Opposition to the Fair Labor Standards Act of 1938, 62 J. of Econ. History 25, 27 (2002) (citing V.O. Key, Jr., Southern Politics 528 (1949)). 
[T] he stout defense by southern Congressman of child labor, in an earlier day, and, more recently, of regional wage differentials with southern workers on the short end, illustrates the indifference of southern politicians toward their non-voting laboring constituents. ${ }^{376}$

Southern congressmen from districts with high numbers of non-voting African-Americans opposed the FLSA, joining with conservative Republicans to block passage for almost a year and then voting against it. ${ }^{377}$ The battle over the FLSA marked the end of the New Deal and the beginning of a new Southern Dixiecrat-Republican coalition that would rule Congress for decades.

Today, the correlation between race and farm work remains. Nationally, approximately $85 \%$ of current farm workers, including children, are members of racial minorities. Today these workers are largely Latino. ${ }^{378}$ In some regions, most especially in Arizona and California, $99 \%$ of farm workers are Latino. ${ }^{379}$ The quid pro quo paid for congressional passage of the FLSA was a heavy price indeed. The cost is felt to this day.

\section{V.CONCLUSION}

From the founding of the American colonies until the present day, child labor has remained a constant feature of our United States economy. This fact has been ratified by political/legal choices made for hundreds of years. The most visible decisions about child labor were made by conservative federal courts, particularly the Supreme Court. Although there have long been legislative attempts to

\section{Id. at 27.}

377. Only $44 \%$ of Southern Democratic senators voted in favor of the FLSA, in contrast with overwhelming support among Democratic senators from the rest of the country. On the vote to pass the House version of the FLSA, a solid majority, fortynine to thirty-seven, of Southern Democratic Representatives, voted against the bill. Democratic congresspersons from other regions were almost unanimous in support, one hundred ninety-four to three. $I d$. at 32 . Even the statutory exemption for agriculture was not enough to bring these southern congressmen to support the FLSA.

378. Dept. of Lab., A Demographic and Employment Profile of U.S. Farm Workers 48-49, http://www.doleta.gov/agworker/report9/naws_rpt9.pdf (March 2005).

379. See Child Lab. Coalition, Children in the Fields Campaign Fact Sheet, http://www.stopchildlabor.org/Consumercampaigns/fields.htm (accessed Feb. 7, 2011) (an increasing number of immigrant children traveling to the United States and finding many migrant farm communities to be almost $99 \%$ Latino). 
ameliorate or end this employment, all have foundered in the face of fierce opposition by employers and others. The ineffectiveness of the FLSA of 1938, supposedly the death knell for child labor, is a result of cleverly drafted exemptions and long-term administrative nonenforcement. The FLSA reflects the complicated and interwoven effect of ideology, economic and political power, and our own "American Dilemma"-race.

The types of jobs youth currently hold are different from those in previous generations. Most of our youth workforce is concentrated in entry-level, age-segregated jobs $^{380}$ with few opportunities for meaningful interaction with adults, skill acquisition or long-term employment. These are simply not career opportunities. ${ }^{381}$ This type of work during adolescence provides few benefits and can jeopardize a successful transition to adulthood.

The big winners from this state of affairs are employers able to hire cheap, unskilled workers, and the sellers of goods and services consumed by this large pool of adolescent buyers. The losers include working youth and society as a whole. While work presents potential benefits, it also poses substantial immediate and long-term risksacademic, health and social-for adolescents and their families. In essence, we are trading the future welfare of children and their families for immediate, short-term gratification. This is an extraordinarily poor trade-off.

I do not believe that all youth must attend school until the age of eighteen. For many, true job training, vocational education and other paths are better suited to their short- and long-term needs. But current child labor reflects little advantage for them and should be radically restructured. Many Americans have enlisted in the worthy crusade to remedy the scandalous abuses of child labor in undeveloped Third World countries. This is praiseworthy, but we should pay equal attention to the problems of child labor here at home.

380. See Greenberger \& Steinberg, supra n. 12, at 51.

381. See id. at 57. 